\title{
THE CASBAH OF ALGIERS:
}

Cultural Heritage as a Political Tool

\author{
Gwendolyn Peck \\ BS Architecture, University of Michigan, 2013
}

\author{
Committee: \\ Sheila Crane (Advisor) \\ Shiqiao Li \\ Andrew Johnston \\ $5 / 1 / 2016$
}

\author{
A Thesis presented to the \\ Faculty of the Department of Architectural History \\ in the School of Architecture at the University of Virginia \\ in fulfillment of the requirement for the degree \\ Master of Architectural History
}


Table of Contents

Introduction $\quad 4$

I. Colonialism and the "Traditional City" $\quad 10$

$\begin{array}{ll}\text { II. Nation Building with Cultural Heritage } & 18\end{array}$

III. World Heritage as an International Image 46

$\begin{array}{ll}\text { Conclusion } & 61\end{array}$

Bibliography $\quad 66$

$\begin{array}{ll}\text { Illustrations } & 72\end{array}$ 
List of Illustrations

Fig. 1 - Sandervalya, Boulevard front de mer, April 18 2008, https://commons.wikimedia.org/wiki/File:Alger-centre_front_de_mer.JPG

Fig. 2 - Jean-Marie Pirard, Etage en surplomb de la rue en haute Casbah, Oct. 20 2007, https://commons.wikimedia.org/wiki/File:Ruelle_dans_la haute_casbah_Alger.JPG.

Fig. 3 - Gerard van Keulen, Algiers c. 1690, https://en.wikipedia.org/wiki/Timeline of Algiers\#/media/File:La cite le port et le mole d Alger.jpg

Fig. 4 - Neurdein frères, Panorama d'Alger. Vue prise de la Casbah, Getty Research Institute, http://hdl.handle.net/10020/2008r3 4020.

Fig. 5 - Sakina Missoum, Alger à L'époque Ottomane: La Médina et La Maison Traditionnelle (Aix-en-Provence: Edisud, 2003).

Left: Dar avec Chbak II.2 Raiah Rabah, 2; Right: Dar I.14 Impasse Sidi Driss Hamidouche, 2.

Fig. 6 - Sakina Missoum, Alger à L'époque Ottomane: La Médina et La Maison Traditionnelle (Aix-en-Provence: Edisud, 2003).

Left: Dwira II.5 Raiah Rabah, 6; Right: Dar II.3 Raiah Rabah, 4.

Fig. 7 - Yves Jalabert, Intérieur de Dar Hassan Pacha. Alger. May 9 2013, https://commons.wikimedia.org/wiki/File:Darhassanpacha_(2).jpg

Fig. 8 - Sakina Missoum, "Algiers. Current state of the historic center," Alger à L'époque Ottomane: La Médina et La Maison Traditionnelle (Aix-en-Provence: Edisud, 2003).

Fig. 9 - Sakina Missoum, "Al-Djaza'ir. Restitution of the urban structure of the Algiers medina," Alger $\grave{a}$ L'époque Ottomane: La Médina et La Maison Traditionnelle (Aix-en-Provence: Edisud, 2003).

Fig. 10 - UNESCO, Kasbah of Algiers - Map of the inscribed property, 1992, http://whc.unesco.org/en/list/565/multiple=1\&unique number $=667$

Fig. 11 - UNESCO, Kasbah of Algiers - Map of the inscribed property, 1992, http://whc.unesco.org/en/list/565/multiple=1\&unique_number=667, Place du Gouvernement (now Place des Martyrs) highlighted.

Fig. 12 - UNESCO, Kasbah of Algiers - Map of the inscribed property, 1992, http://whc.unesco.org/en/list/565/multiple=1\&unique_number=667, Bab Azzoun, Bab el-Oued, and Marine streets highlighted. 
Fig. 13 - Alexandre Leroux, Algiers Harbour, 187-, Getty Research Institute, http://hdl.handle.net/10020/2008r3_4300.

Fig. 14 - Ruins of Ali La Pointe house, September 30, 1957,

https://en.wikipedia.org/wiki/Battle of Algiers_(1956\%E2\%80\%9357)\#/media/File:Casbah-cache-Ali-la pointe.jpg

Fig. 15 - Dorothée Vauzelles Barbier et al., Schematic from "Mission d'Assistance préparatoire Revalorisation de la Casbah d'Alger" (Paris: UNESCO, 1978), http://unesdoc.unesco.org/images/0003/000321/032150fb.pdf, 49.

Fig. 16 -Plan Permenant de Sauvegarde et de Mise en Valeur le Secteur Sauvegardé de la Casbah d'Alger. Before work and after work. http://www.casbahdalger.dz/001.pdf. 
Introduction

Walking down the wide boulevard along the Mediterranean, surrounded by white colonnades, the edge of Algiers leaves no hint of what lies inside. (Fig. 1) A turn down a perpendicular street leads into the city, with tall neoclassical buildings lining the large street. Wandering further into the urban fabric, the scene begins to change. As the buildings grow more dense and the street narrows, it is clear that this is a different city; this is the Casbah. (Fig. 2) The name is a transliterated misnomer, a remnant of the French colonial era that refers today to a very specific area of Algiers. The original word 'qasba' means fortress in Arabic, and refers directly to the citadel located at the top of the district. Al-Djaza'ir was the name ascribed to the city that eventually gave its name to the modern city and the entire country. This medina has a long history that goes back past the Ottoman era, exhibiting an architectural style similar to its neighboring North African countries, Morocco and Tunisia. Setting Algiers apart is a dramatic topography that puts the mass of buildings on full display to those who approach from the harbor. (Fig. 3) A protective string of natural islands connect back to the mainland where a heavily fortified city rises up the steep hills. Inside the walls, the architecture depicted in the 1690 engraving is homogenous with the occasional dome of a mosque interrupting the otherwise simple structures. The amount of windows shown is unrealistic, however. The typical Casbah house does not have many exterior windows but rather relies on a central courtyard for ventilation purposes. Taken from the interior of the district in the 1880 s, a Neurdein Frères photograph provides a better understanding of the buildings within, or at least their exteriors. (Fig. 4) The introversion suggested by the stark exteriors captivated the minds of the French who colonized the city in 1832 .

Roughly 5,000 houses were a part of the Casbah when the French arrived. ${ }^{1}$ These varied in size from modest to palatial, all with similar planning. The entry hall, or sqifa, created a bent-axis that kept the interior hidden even when the main door was opened. (Fig.5) A courtyard, or wast al-dar, acted as the

\footnotetext{
${ }^{1}$ Federico Cresti, "Algiers in the Ottoman Period: The City and Its Population," in The City in the Islamic World, ed. Salma K. Jayyusi, vol. 1, 2 vols. (Boston: Brill, 2008), 407-43.
} 
central element that vertically connected the dwelling and led to rooms. (Fig. 6) Roof terraces were another standard element that managed to create another world above the streets with their connections. (Fig. 4) The patterned interiors and architectural flourishes strongly juxtapose the plain exteriors. (Fig. 7) Rather than understanding these design decisions as foreign and belonging to the past, in the similar context of the old Fes medina, Said Ennahid has offered explanations for each decision in his article, “Access Regulation in Islamic Urbanism: The Case of Medieval Fès." ${ }^{2}$ Though his evidence comes from Medieval Fès, the planning system translates to the Casbah as well. Bent-axis entryways and minimal exterior windows are privacy measures for inhabitants. The courtyard acts as the central element of a passive cooling system meant to mitigate the harsh Mediterranean conditions. Not only does it ventilate the rooms that surround it, but its verticality also keeps the sun out of the interior for most of the day. Similarly, he suggests that the narrow, winding streets often perceived as illogical are created to keep the sun off of the street and to keep the wind from blowing out cold air. The density of the buildings is understood as a way to minimize the exposure of exterior walls to the sun, as well as keeping the streets below covered from the sun. It was not always understood in such a logical way, however. Years of interventions, neglect, and conflict have resulted in a present-day district of a larger city that is in disrepair. The original estimate of 5,000 houses has been reduced to $1,800,615$ of which are considered traditional houses. ${ }^{3}$ (Fig. 8) This dramatic change is the subject of this study. Understood in the context of the political shifts over time, the Casbah becomes a political tool for those in power. Since French colonization, that group has not coincided with the residents of the Casbah.

There is a considerable body of work that concerns Algeria, and a great deal of interest in Algiers in particular. A general history by John Ruedy in Modern Algeria sets up a solid framework to delve further into specific issues in Algerian history. The history of the area known today as Algeria is long and

\footnotetext{
${ }^{2}$ Said Ennahid, “Access Regulation in Islamic Urbanism: The Case of Medieval Fès," The Journal of North African Studies 7, no. 3 (Fall 2002): 119-34.

${ }^{3}$ Nora Chergui, "Le Président de la Fondation Casbah: <<Il faut sauver la Médina >>," El Moudjahid, February 22, 2016, sec. Nation.
} 
filled with different antagonists. Algiers itself, the city that gave the state its name, was initially a Phoenician trading post named Icosium. Trading hands from the Romans to the Arabs to the Spanish, a sense of lengthened political stability was introduced when the Ottoman Empire took control of the city in the early 16 th century and began to describe the area of modern day Algeria. L'Algérie en héritage, art et histoire $^{4}$ and Sites et monuments antiques de l'Algérie ${ }^{5}$ takes a pre-Ottoman focus, using the material culture as the primary subject of the book. Roman ruins in the north along the Mediterranean, as well as monumental structures in the south comprise these books and provide an image of the origins of the country and its heavily mixed culture.

The Ottoman Empire held loose control over the city and larger country, sending administrative and military personnel to Algiers and installing a governor, called the Dey. For the purposes of this study, histories focusing on this era were not consulted. Rather, architectural histories focusing on the period such as Sakina Missoum's intricate study Alger à l'époque ottomane and Lucien Golvin's Palais et Demeures d'Alger à la période ottomane were used to better understand the Casbah on a micro scale concerning individual houses and how they form a district. Though the two hold similarities in the methodology of their studies, the time between the two echoes a shift in understanding of the site. Missoum, writing fifteen years later, focuses on more than just residential spaces within the Casbah, working towards an understanding of the entire city before French interventions on the urban fabric.

Three hundred and thirteen years under the Ottoman Empire ended with an incident involving a "peacock feather fly whisk." A French envoy sent to enquire about a debt was slapped three times in 1827, offering the instigation King Charles X of France needed to justify conquest. Algiers was taken in 1830, immediately forced to raise the French flag over the citadel. ${ }^{6}$ The French held control over Algeria

\footnotetext{
${ }^{4}$ Eric Delpont, Djamila Chakour, and Yannis Koïkas, eds., L'Algérie En Héritage, Art et Histoire (Arles: Institut du Monde Arabe/Actes Sud, 2003).

${ }^{5}$ Jean-Marie Blas de Roblès and Claude Sintes, Sites et Monuments Antiques de l'Algérie (Aix-en-Provence: Édisud, 2003).

${ }^{6}$ John Ruedy, Modern Algeria: The Origins and Development of a Nation, Second (Indianapolis: Indiana University Press, 2005), 46.
} 
for one hundred thirty-two years in an unusually close relationship. Ultimately, France considered the large African nation to be an extension of France despite a continual reluctance to allow native Algerians to gain French citizenship. This strange colonial relationship between France and Algeria has generated a plethora of scholarship on nearly every imaginable subject. Zeynep Çelik, however, is an integral author with her work on the urban fabric of Algiers during colonization. She takes the 132 years of colonization and exhaustively discusses the treatment of the site by the French, tying in the political relationships to provide an overwhelmingly complete study of the Casbah in Urban Forms and Colonial Confrontations: Algiers under French Rule. ${ }^{7}$ Her edited volume with Julia Clancy-Smith and Frances Terpak based on an exhibition by the same name at the Getty Research Institute, The Walls of Algiers is another brilliant source of scholarship on this period. ${ }^{8}$ After an eight-year war with the French, Algeria finally gained independence. The post-independence era is not as populated with scholarship. The conflict of the 1990s has drawn the most critical work, with contemporaneous works such as James Ciment's Algeria: The Fundamentalist Challenge ${ }^{9}$ and Luis Martinez's The Algerian Civil War 1990-1998. ${ }^{10}$ Providing a more historical view of the conflict is James D. Le Sueur's Between Terrorism and Democracy: Algeria since 1989, published in 2010. ${ }^{11}$ The amount of literature on the two major conflicts in Algerian history points to an overall interest in conflict that rings true in architectural history as well. Beyond literature focusing on the distant past, architectural interest focuses on the colonial conflict, acted out in the material world, as seen in Çelik's work. Post-independence work concerning the Casbah in particular is more difficult to find. Henry Grabar focuses on the immediate post-colonial period, finding little evidence of new construction. ${ }^{12}$ Kahina Amal Djiar has recently written a few articles focusing on the story of the Casbah

\footnotetext{
${ }^{7}$ Zeynep Çelik, Urban Forms and Colonial Confrontations: Algiers under French Rule (Berkeley: University of California Press, 1997).

${ }^{8}$ Zeynep Çelik, Julia Clancy-Smith, and Frances Terpak, eds., Walls of Algiers: Narratives of the City through Text and Image (Seattle: The Getty Research Institute, in association with the University of Washington Press, 2009).

${ }^{9}$ James Ciment, Algeria: The Fundamentalist Challenge (New York: Facts on File, Inc., 1997).

${ }^{10}$ Luis Martinez, The Algerian Civil War 1990-1998, trans. Jonathan Derrick (London: Hurst \& Company, 2000).

${ }^{11}$ James Le Sueur, Between Terror and Democracy: Algeria since 1989 (New York: Zed Books, 2010).

${ }^{12}$ Henry S. Grabar, "Reclaiming the City: Changing Urban Meaning in Algeria after 1962," Cultural Geographies 21 (2014): 389-409.
} 
with a particular focus on the residents in a 2009 article. ${ }^{13}$ There are multiple examples of international interest in the Casbah in news articles ranging from 2007 to 2016, from the Smithsonian, the New York Times, and Reuters. These stories highlight the Casbah and its dilapidated state, often trying to find an explanation for this seeming neglect. There are some strong observations, but ultimately within the limitations of the medium, a significant portion of the story is glossed over. A more scholarly treatment of the subject comes from Djaffar Lesbet who published a long history of the Casbah in the mid-1980s along with his own assessment of the state of the Casbah and how preservation work should proceed. ${ }^{14}$ Though he mentions studies on the site done by various groups, he lacks detailed analysis of the reports and their relationship to the larger image of international preservation. The UNESCO documents concerning the Casbah, supported by Algerian laws concerning preservation make up the backbone of this study. Several reports on the Casbah were written between Algerian Independence and the Casbah's inscription on the UNESCO World Heritage List that detail a national and international interest in the site and an evolving understanding of the medina. What results is a sense of politics swirling incessantly around the Casbah. Here, this information is presented is an examination of the various ways that the Casbah and its memory and meaning is used by different groups in power. It is important to note that the majority of the sources are in English, some in French and none in Arabic. This is a significant blind spot that could be addressed in future iterations of this work. The sparse inclusion of the actual people who are affected by this issue is another area that should be treated moving forward.

In this study, the UNESCO documents are the most critical sources. They are woven in with Algerian history, Algerian laws concerning preservation, and a developing international understanding of preservation, to create an image of the Casbah as a site used by various parties for their own ends. Framed with Shirine Hamadeh's "Creating the Traditional City: A French Project," the first chapter will discuss

\footnotetext{
${ }^{13}$ Kahina Amal Djiar, "Locating Architecture, Post-Colonialism and Culture: Contextualisation in Algiers," The Journal of Architecture 14, no. 2 (April 2009): 161-83.

${ }^{14}$ Djaffar Lesbet, La Casbah (Algiers: Office des Publications Universitaires Alger, 1985).
} 
the French interventions in the Casbah in the context of a more general political history. The colonial relationship between the French and Algerians is critical to understanding the image and use of the Casbah during this period. Following Independence, the second chapter will consider the drive to preserve the Casbah, spearheaded by government officials. A series of UNESCO documents will be interwoven with the concurrent political policies similarly aiming to clarify the Algerian identity. Understanding the movement towards preservation as a nationalistic activity driven by contrasting images of the state as postulated by Mark Jarzombek, the Casbah becomes a site whose preservation can bind together the past and future. The final chapter picks up in 1992 after the Casbah gains World Heritage status. A shift in documentation process as well as political instability mark the beginning of this chapter. The major dialogue of this chapter follows the relationship of the government and UNESCO. Using scholarly criticism of the World Heritage program, the past twenty-four years are organized to elucidate the seemingly static situation of the Casbah. Here it becomes clear that this is not an isolated Algerian issue but a case study in the larger problem of politics playing a larger part in UNESCO. Permeating through this work is the disparity between interest in the site and its preservation, and the difficult web of issues in the way. Concluding this deep look into the preservation of the Casbah is a move onto a more human level, considering the realities of life in the district and ultimately, what is being saved and for whom. Though several themes run through this story (and several more have been left out), it is the continuing use of the district as a political tool with little attention to the residents that demands attention. Though theoretically a bridge between the past and the future, a selective memory continues to ignore major issues that remain in the way of progress. 


\section{I: Colonialism and the "Traditional City"}

The present-day Casbah is considered a traditional Arab city, a district enclosed by a sharply contrasted colonial architectural style. Sure enough, its significant aesthetic change occurred over the course of French colonization. The city that they invaded in 1830 was a far more cohesive unit. (Fig. 3) A recreated version of the urban fabric before French occupation has been created by Sakhina Missoum in plan form to offer an understanding of the pre-colonial structure of the city. (Fig. 9) Compared to a plan of the Casbah today, the major differences are clear. (Fig. 10) The lower area near the water, the Marine Quarter, has been completely changed. The lower Casbah, the area below the hill, has been regularized and opened up. Shirine Hamadeh's chapter, "Creating the Traditional City," in Forms of Dominance: on the Architecture and Urbanism of the Colonial Enterprise discusses the dynamic of French rule in North Africa through the built environment. Focusing on roughly 100 years, 1830-1930, three particular cities, Algiers, Tunis, and Rabat are used to discuss the treatment of the existing architecture by the French colonists. She suggests that policies concerning the urban fabric are part of a broader strategy of control implemented by the French. In this context, she explores several different approaches to the Casbah, each echoing evolving understandings of culture, power dynamics, and preservation. The ultimate effect of these policies, whether conscious or not, was to tie the Casbah and Algerian civilization to the past in contrast to French progress. Here, these shifting policies will be further understood in the larger historical context by widening the temporal scope to cover the entire French colonial period and shrinking the geographic scope to only Algiers.

A desire for control over the urban fabric is evident from the beginning of colonization The first of the French policies concerning the city was direct and destructive, echoing a desire to assimilate the native population. ${ }^{15}$. Immediate actions on the urban fabric were executed for military reasons; widening

\footnotetext{
${ }^{15}$ Shirine Hamadeh, "Creating the Traditional City: A French Project," in Forms of Dominance: On the Architecture and Urbanism of the Colonial Enterprise, ed. Nezar AlSayyad (Brookfield, USA: Avebury, 1992), 245.
} 
the streets was necessary to allow troops better and quicker access to the city. ${ }^{16}$ Critical demolition was necessary to create Place du Gouvernement, with residential and commercial sites being sacrificed for the new public square. ${ }^{17}$ (Fig. 11) The large open space near the harbor was placed in front of the Janina Palace, home to the Deys of Algiers prior to 1816, making its location just as meaningful as the demolition. Bab Azzoun, Bab-el Oued, and Marine streets were all widened to accommodate troops and the French desire for a more spacious city. (Fig. 12) These first projects have little to do with building and much more with applying a French understanding of space to a foreign city.

Though the military concerns were directed towards other European powers rather than the native population, a show of power within the country was necessary. Resistance against French colonization was not vanquished easily. Amir 'Abd al Qadir led anti-French forces in the south of the country for seventeen years after the fall of Algiers. Though the first reaction was to send military forces, 'Abd al Qadir was so successful that eventually he had to be dealt with politically. The Desmichels Treaty was signed in 1834, conceding land and sovereignty to the Amir. Further military defeat led the French to sign another treaty in 1837 , the Treaty of the Tafna. This time, the agreement was more explicit in the boundary between French-ruled and Algerian-ruled land, but gaining French recognition was not the last of 'Abd al Qadir's problems. Not all Algerians were united in following the Amir. He had to launch campaigns against other regional leaders to establish his power and ability to rule. Though he never posed a direct threat to Algiers, it was not until after 'Abd al Qadir was caught near the Morocco border and extradited to France that the French extended beyond the walls of Algiers. The fortifications that defined the city were enlarged by 1849 , foreseeing growth of the city. The style and layout of the expansion was not yet decided, but the designers would certainly be French. As Europeans moved to Algiers, the upper Casbah remained a site for Algerians while the lower area where the majority of interventions had taken

\footnotetext{
${ }^{16}$ Zeynep Çelik, Urban Forms and Colonial Confrontations: Algiers under French Rule (Berkeley: University of California Press, 1997), 27.

${ }^{17}$ Çelik, Urban Forms and Colonial Confrontations, 28.
} 
place became almost exclusively European. Beyond the enlargement of Rue de la Lyre, little work was done that directly affected the upper Casbah. ${ }^{18}$ Though this urban fabric was left alone, its inhabitants were not.

As early as 1845 , the idea was expressed that the two different civilizations required different architecture to fit their lifestyles. Spatial control beyond architectural style was easily inserted into this idea, with the assertion that access to the port would be more important for the French and their commercial activities. ${ }^{19}$ The initial destruction, however, took on a negative air as it destroyed the exoticism that fit the French image of Algeria. ${ }^{20}$ The modern day harbor view of Algiers is defined by these changes to the city. (Fig. 13) Large colonnades lining the water, lifting people up to the level of Rue de l'Impératrice to a wide boulevard lined with a smaller colonnade gave a distinct European feel to the city. Instead of indigenous architecture rising out of ominous fortifications, the exotic styles rose from a heavily European base.

Driven by the ideas of Napoleon III, the policy of this era held that the native style was a pure expression that needed to be saved. As Hamedeh points out, it was not Algiers being preserved for the Algerians but rather an image of Algerian culture being preserved for exhibition. ${ }^{21}$ This policy of separation was further entrenched by the code de l'indigénat, which was introduced in the 1870s and remained in effect until after WWII. ${ }^{22}$ This law was applicable only to Muslims and further highlighted the power structure within Algeria. Most of the rules were clearly implemented to punish those who did not adhere to French rules and the French system. Simple things like not declaring birth or deaths and begging in different neighborhoods were suddenly punishable by law. ${ }^{23}$ This legislation suggests that getting all Algerians to respect French rule was not a simple task. Though stylistically the French wanted to keep Algeria pure,

\footnotetext{
${ }^{18}$ Çelik, Urban Forms and Colonial Confrontations, 36.

${ }^{19}$ Çelik, Urban Forms and Colonial Confrontations, 26.

${ }^{20}$ Hamedeh, "Creating the Traditional City: A French Project," 246.

${ }^{21}$ Hamedeh, "Creating the Traditional City: A French Project," 248.

${ }^{22}$ Ruedy, Modern Algeria, 89.

${ }^{23}$ Ibid.
} 
the Algerians were expected to live within the French system. Calling out the flaws in colonial logic, the French could accept different architectural styles but not lifestyles that made administration difficult. Though no French projects affected the upper Casbah, there was no maintenance work done on the district either. ${ }^{24}$ In this context of neglect, however, the residents were compelled to create a system of management within the community to keep the space livable. ${ }^{25}$ The same surface treatment of the Algerian people and native architecture shows an avoidance of deeper issues.

Eventually, the Casbah as the image of Algerian culture in the capital was not enough. After all, European travelers were seeking exotic places, not ones that reminded them of home. Just as the neglect of the upper Casbah could be optimistically read as preservation or cultural respect, this next phase could be understood as either appropriation or emulation. A desire to 'Arabize' their buildings in a style called "Arabisances" led to intense study of the native style, both in Algeria and other North African countries. ${ }^{26}$ Though the research makes it look as if there was a real interest in Algerian culture, that interest was largely superficial. The reasons and history behind the native architecture were not elements that interested the French; nor were the introverted façades of the traditional houses of the Casbah sought after as a style. A pure Algerian style was also not the goal of those behind the movement. Georges Giauchain, a proponent of the style in Algeria, believed that Algerian style was no longer exotic enough to capture the interest of Europeans. ${ }^{27}$ The superficial response was to mix and match North African styles to create buildings to capture the eye and imagination of travelers. Traditional architecture, in this case, was not being experienced nor preserved but ripped apart visually to be used as ornament to recreate the image of the Orient.

\footnotetext{
${ }^{24}$ Çelik, Urban Forms and Colonial Confrontations, 38

${ }^{25}$ Lesbet, La Casbah, 39-40.

${ }^{26}$ Hamedeh, "Creating the Traditional City: A French Project," 249.

${ }^{27} \mathrm{Ibid}, 250$.
} 
A large celebration in 1930 marked 100 years of French rule in Algeria. In a way, the cultural preservation ideas of Napoleon III were brought back but with a more experienced set of urban policies. ${ }^{28}$ By this time, the Casbah was enclosed by a modern European city and locked into the past. ${ }^{29}$ The sense that it was the last material evidence of a pre-colonial culture imbued it with new value that would spin French policy towards preservation. Critically, it was recognized that preservation by neglect was not an option; action to conserve the district would be necessary. This desire to preserve was still colored by misconceptions of the Casbah. Rather than understanding the underlying structure of the Casbah and the justifications for the spatial organization of the houses, designers pinpointed issues that misunderstood the urban fabric. Design concerns for the Casbah included hygiene in the densely packed district and the layout that the French considered illogical and unorderly. One plan by Jean Bévia suggested that buildings in poor condition should be torn down and their lots left empty as "ventilation." ${ }^{30}$ As the structure of the Casbah relies on the dense housing as a form of support, this method of demolition would be akin to haphazardly taking pieces out of the Eiffel Tower. Bévia's plan highlighted the importance of aesthetics, suggesting rules regarding the outward appearance of buildings. ${ }^{31}$ Implementation would also be a difficult part of the plans. The need to conserve the upper Casbah would take considerable money and time. One plan compromised the life of the Casbah for its survival. E. Pasquali suggested removing the population of the upper Casbah to turn the entire district into a museum. ${ }^{32}$ An actual regulation in 1931 set the onus on residents, legally. ${ }^{33}$ It aimed to maintain the aesthetic quality of the district and found a system that would involve the French government only in a managerial position. Though plans were designed by several prominent architects including Le Corbusier, nothing was ever executed. Instead,

\footnotetext{
${ }^{28}$ Çelik, Urban Forms and Colonial Confrontations, 39.

${ }^{29}$ Hamedeh, "Creating the Traditional City: A French Project," 253.

${ }^{30}$ Çelik, Urban Forms and Colonial Confrontations, 41.

${ }^{31}$ Ibid.

${ }^{32}$ Ibid, 45.

${ }^{33}$ Ibid, 41 .
} 
echoing the political issues of the time, the surface remained the same while the situation worsened underneath.

As the Casbah shifted from a repository for a subjugated population to a space of memory for the colonists themselves, Algerian nationalism began to bloom. Four Algerian movements grew in the 1920s, all with different solutions to their grievances against the French state. The Fédération des élus indigènes, Islamic Reform movement, Etoile nord-africaine, and Algerian Communist movement had varying ideas of how to fight back against their French oppressors, ranging from working within the system to Algerian nationalism. ${ }^{34}$ Following the rise of the Popular Front in France in 1936, three of the groups joined together to create an Algerian Muslim Congress. The only group excluded was l'Etoile nord-africaine, the most extreme nationalist organization. The first Algerian Muslim Congress drafted the Charter of Demands of the Muslim Algerian People which, as the title suggests, outlined a series of demands. Ruedy suggests that the ultimate failure of the Congress a disagreement concerning their future relationship to France and its culture. ${ }^{35}$ Though a bill was written up to address the grievances stated by the Congress, the Blum-Viollette Bill was not ultimately passed. The flirtation with progress followed by defeat forced most Algerians towards the platform of nationalism, setting the country on a path towards major conflict.

The French treatment of the Casbah came to a climax as the spatial isolation was militarized during the War of Independence. On October 31, 1954, the CRUA ${ }^{36}$ issued a call to arms that created the Front de libération nationale, or FLN. In particular, the Battle of Algiers, from late 1956 to early 1957, used exaggerated versions of past French policies to treat the heavily native-populated district that had become an FLN headquarters. Setting up checkpoints at points of access between the European city and the upper Casbah exacerbated the separation that had been strategically imposed over time through urban projects. The superficial interest that characterizes the overall French relationship with the Casbah

\footnotetext{
${ }^{34}$ Ruedy, Modern Algeria, 131.

${ }^{35}$ Ibid, 143.

${ }^{36}$ Comité révolutionnaire d'unité et d'action, a group created in the spring of the 1954 following the dissolution of a coalition group aiming to gain independence through political means.
} 
unearthed a secret weapon for the FLN operating within the intimate site. Suddenly, a superior spatial understanding of the complex district and a tight community brought together in solidarity, even before a violent challenge, offered the perfect headquarters for rebellion. As the FLN operatives continued to elude French forces, their frustration with the Casbah came to a head with the incredibly violent acts of invasion and bombing. Ali la Pointe, an important moudjahidin, ${ }^{37}$ was killed in his residence in the Casbah when it was bombed by the French paratroopers. The ruins remain today as a reminder of this brutal military action against the Algerians and their city. (Fig. 14) It wasn't until long after the Battle of Algiers had ended that the French realized that they had lost, but the urban terrorism of the Battle of Algiers brought international attention to the ongoing conflict. The Evian Accords instituted a ceasefire and a decisive vote of the Algerians on July 1, 1962 finally made an independent, internationally recognized Algerian state a reality.

French policies during 132 years of colonization successfully relegated the Casbah, its planning, and its style to the past. Treated as a synecdoche for Algerian culture by the French, the post-independence era would need to focus a considerable amount of energy on creating an Algerian identity that was also highly modern. The localized alterations to the old city of Al-Jaza'ir point to a need to assert Western spatial logic on top of a foreign urban plan. The inability to live in that foreign urban fabric, whether due to a lack of spatial conception of the city or discomfort, was not conducive to controlling the city. In contrast, the lack of interventions on the upper Casbah left a carefully demarcated space for the natives as well as a convenient remnant of the past to marvel at. The spatial policies of the period care little for the natives living in the Casbah, or for the design factors that determined its exotic form. Already linked to the past, physically separated from the rest of the city and constricted to bar further growth, the Casbah was only allowed to participate in history through its continued use. As a space of memory for the French, the Casbah was always an object to be observed but never truly

\footnotetext{
${ }^{37}$ Arabic for 'warrior,' and a term that gained an unbreakable connection with the War of Independence.
} 
experienced, thus remaining in the past. For the Algerians who lived there, creating a community gave meaning to the space beyond its image. Many of the management issues presented by the Casbah would confront the independent Algerian government as well, though mitigating the distinction between the modern city and traditional city created by the French is still a significant hurdle. 


\section{II: Nation Building with Cultural Heritage}

March 19th, 1962 marked the ceasefire in the war between Algeria and France, a day after the Evian Accords were signed. The shift was swift as Europeans fled back to France leaving the city of Algiers essentially a ghost town. As if to emphasize the level of French immersion, even statues were extracted leaving pockets of memory to be filled. ${ }^{38}$ Now, this city with an architectural language of divide between colonists and natives, was united as Algerian. Yet that raises the question, what did it mean to be Algerian? Nationalism in Algerian history has been a contentious subject, though most scholars assert that any sense of an Algerian nation was severely limited prior to French occupation. As described in the previous chapter, 'Abd al-Qadir provides a strong example of Algerian resistance to the French, and remains today an icon of the nation. The politicization of the Algerian intelligentsia in the 1920s set in motion a series of incidents eventually leading to the War of Independence. These instances point to a unity prior to independence, but it does not negate the necessity of nation building under the new Algerian state. More than just a functioning bureaucracy, the country needed to build an identity to solidify the unity of the nation.

Jonathan N.C. Hill discusses the successive programs enacted by Ahmed Ben Bella, Houari Boumedienne, and Chadli Benjedid to build a national identity over the course of thirty years in his article "Identity and Instability in Postcolonial Algiers". He organizes his investigation around the three presidencies, highlighting the desire to create a united façade while grappling with the multicultural reality of the country. Critical to his article is an understanding of the underlying political motivations, arguing that hegemony, as expressed through a single political party, was necessary in the post-colonial context of Algeria to combat any political upheaval. ${ }^{39}$ Though Hill's interest is primarily in political

\footnotetext{
${ }^{38}$ Henry S. Grabar, "Reclaiming the City: Changing Urban Meaning in Algeria after 1962," Cultural Geographies 21 (2014): 396.

${ }^{39}$ Jonathan N.C. Hill, "Identity and Instability in Postcolonial Algeria," The Journal of North African Studies Vol. 11, No. 1, March, 2006, 4.
} 
decisions, the political uses of history should also be considered. In his article, "The Metaphysics of Permanence - Curating Critical Impossibilities," in Log, Mark Jarzombek suggests that architectural preservation exists at the intersection of cultural nationalism and state nationalism. ${ }^{40} \mathrm{He}$ describes the former as seeking "to preserve and enhance the distinctiveness of a national consciousness through the selective constructions of history and tradition," while state nationalism focuses on "modernization and urbanization. ${ }^{״ 41}$ By placing preservation at the intersection of the two, the Casbah itself has the chance to act as the bridge between the past and future.

Here, the thirty years of nation building discussed by Hill between Independence and the designation of the Casbah as a World Heritage site is reframed as the story of the Casbah as cultural and state nationalism. Similar to Hill, the sources of interest here will be government documents, though their inherent focus on the past offers a further understanding of the politicization of history and preservation, as described by Jarzombek. Several UNESCO reports on the Casbah, considering its past and possible futures, were commissioned by the Algerian government during this period. The plethora of UNESCO surveys range in length of report, length of mission, scope of investigation, depth of findings and size of the investigating teams. The Algerian government is mentioned in nearly all of them as having some influence on the focus of the study or its initiation. This national interest is echoed in the legislation passed during this time in relation to heritage. Further contextualized by a developing understanding of World Heritage, this chapter will once again place the Casbah as a passive site, acted on multiple levels, this time in a more theoretical manner, like an animal being observed and assessed.

Almost four months after the ceasefire, Algeria celebrated its first Independence Day on July 5th, 1962. On July 22nd, Ahmed Ben Bella took power eliminating any questions of an uneasy power shift. He had been a critical member of the FLN, and his role as president kicked off the glorification of the FLN, which became the sole political party. A year later he was officially elected the first president of

\footnotetext{
${ }^{40}$ Mark Jarzombek, “The Metaphysics of Permanence - Curating Critical Impossibilities," Log 21 (Winter 2011).

${ }^{41}$ Ibid, 125.
} 
Algeria. Behind the guise of a smooth transition into self-governance, a more complex story unfolded. Ben Bella's ascension to president relied on the support of Houari Boumediene and the Armée de libération nationale (ALN) over a rival play for power by the GRPA. ${ }^{42}$ As Hill describes, this underlying conflict demanded a consolidation of power and identity. Under Ben Bella, the Algerian identity relied on three generalizations, asserting that the country was Arab, Muslim, and socialist, as documented by the Tripoli Programme and the 1963 constitution. ${ }^{43}$ These three elements simplify and deny a complex country, a criticism that is often used to help explain the strife of the ' $90 \mathrm{~s} .{ }^{44}$ Within each of these identificative assertions there is a contradiction.

Arabization is the term used for the advancement of Arabic as the national language to replace the colonial French in every aspect of life. This identity building tactic pushed for Arabic as the language of government documents and education but it sowed seeds of discord as well by ignoring the native Berber language, Tamazight. Education continued to have two tracks, bilingual and exclusively Arabic, further entrenching this divide. The bilingual track tended to be taken by Berber and middle class children while the Arabic track was primarily filled by children from rural Algeria and those new to the cities. ${ }^{45}$ When these children finally reached the job market, a preference was shown to the bilingual candidates, which only widened the socioeconomic divide.

Though the majority of the population was Muslim, there were varying positions on how much religion should factor into the political state. The FLN did not consider the country a theocracy and had no impetus to move in that direction. In the post-independence context, as Ruedy points out, Arabization was considered to go hand in hand with Islamization while French suggested secularization. ${ }^{46}$ The issues raised by a wholehearted acceptance of socialism were not immediately visible in post-independence

\footnotetext{
${ }^{42}$ Ruedy, Modern Algeria, 193.

${ }^{43}$ Hill, "Identity and Instability in Postcolonial Algeria,"6-7.

${ }^{44}$ See Ruedy, Le Sueur, Hill

${ }^{45}$ Ruedy, Modern Algeria, 228.

${ }^{46} \mathrm{Ibid}, 207$.
} 
Algeria. Socialism would influence how the economy was built, but ultimately a socioeconomic divide emerged that highlighted the government corruption in the system.

Economically and socially, Algeria exhibited state nationalism as described by Jarzombek.

Despite the socialist rhetoric and an eye towards the future, Algeria still had a large rural population in the immediate post-independence era. Despite the rhetoric of the era that presented the government as the expression of the people, the $70 \%$ rural population was more focused on solidifying their identity around mosques through new building projects and restoration. ${ }^{47}$ In the context of a larger population boom, people flowed towards cities in staggering numbers and a housing crisis emerged that could not be fixed quickly. The urban population grew from 3.9 million to 7 million between 1966 and 1977 while the total population increased by five million over the same period. ${ }^{48}$ Even though the Algerians gained independence, the general state of French oppression for over a century meant that the fledgling state lacked skilled workers in several sectors. Even if the state had had funds to build a new architecture to reflect a new, independent Algerian identity, architects and engineers were unavailable. ${ }^{49}$ In Algiers, residents of the Casbah filled in the empty apartments of the lower Casbah, leaving behind their old homes to rent out to newcomers. ${ }^{50}$ Since outwardly expressing this new Arab, Muslim, and socialist identity was not initially possible through massive construction programs, so as an act of taking back the city, smaller interventions such as renaming streets and sites were usual. ${ }^{51}$ Alexandre Lézine, a UNESCO observer wrote in 1966 that "les rues d'Alger ont été débaptisés récemment mais aucun plan nouveau ne nous a été accessible," suggesting that the importance of this action was more symbolic than functional. ${ }^{52}$

\footnotetext{
${ }^{47}$ Ibid, 197.

${ }^{48}$ Ibid, 219.

${ }^{49}$ Alexandre Lézine, "Algérie conservation et restauration des monuments historiques" (Paris: UNESCO, July 1964), http://unesdoc.unesco.org/images/0013/001357/135791fo.pdf, 3.

${ }^{50}$ Kahina Amal Djiar, "Locating Architecture, Post-Colonialism and Culture: Contextualisation in Algiers," The Journal of Architecture 14, no. 2 (April 2009): 174-175.

${ }^{51}$ Grabar, "Reclaiming the City," 399.

${ }^{52}$ Alexandre Lézine, "Algérie conservation et restauration des monuments historiques" (Paris: UNESCO, August 1966), UNESCO, unesdoc.unesco.com, 24. Translation: "the streets of Algiers have been debaptised recently but no new plan was accessible to us."
} 
With limited capabilities to change the urban fabric, the historical fabric would become the image of Algeria, embracing cultural nationalism.

On an international stage, UNESCO was advancing the status of historic preservation. The first document released by the organization concerning preservation was the "Recommendation Concerning the Safeguarding of the Beauty and Character of Landscapes and Sites" in $1962 .{ }^{53}$ Included in the document are several familiar prescriptions, reflecting the importance of this recommendation as a basis for further policies. Particularly important is the idea that "the studies and measures to be adopted with a view to safeguarding of landscapes and sites should extend to the whole territory of a State..."54 This sentiment is evident in the very first UNESCO study on Algeria, that considers sites across the country rather than valuing the heavily populated northern area alone.

Alexandre Lézine's first study of Algeria in 1964 is crippled from its beginning. Covering the entire country in six weeks, he produces a short list of five national monuments that he considers to be the most valuable. He is beholden to the traditional idea of a monument as being large, old, and often ruinous. As a result, he chooses sites that are remarkable yet unimaginative. For example, he divides the sites based on their identifying ties, considering pre-Roman, Roman, and Islamic monuments with two listed in each category. ${ }^{55}$ The Casbah is not found on the list, nor is it mentioned as a critical landmark in his description of Algiers. The sites chosen are Djebar A, the Medracen, Timgad, Cherchell, Mansoura, and the minaret of Al Qa'la of Beni Hammad. ${ }^{56}$ The sites are scattered throughout the country, suggesting that Lézine did survey a great deal of the country. The first two are tomb structures, ${ }^{57}$ the next three are settlements and the last is a specific ruin from an early Arab empire rooted in Algeria. All six predate

\footnotetext{
${ }^{53}$ O'Keefe \& Prott, eds., Cultural Heritage Conventions and Other Instruments, 220.

${ }^{54}$ Ibid, 3.

${ }^{55}$ Though the document only shows five, the next page mentions the minaret of the Qal'a as one of the first two to be seriously approached as preservation projects. Based on this and the off-centered text on the page, and examples later in the document of an abrupt shift from one page to the next (page 8 to 9 , for example), it seems likely that the last one was more or less erased through human error.

${ }^{56}$ Lézine, "Algérie conservation et restauration des monuments historiques," 1964, 3.

${ }^{57}$ Eric Delpont, Djamila Chakour, and Yannis Koïkas, eds., L'Algérie En Héritage, Art et Histoire (Arles: Institut du Monde Arabe/Actes Sud, 2003), 110, 118.
} 
Ottoman rule and are located outside of cities (the three settlement sites are in various states of ruin) further suggesting a predilection for stand alone sites not complicated by their place in a larger urban fabric. As ruins, they also have an end date to their use and a stronger tie to the past than the present. In the case of their preservation, none of these sites would need to contend with the needs of a living population nor with their changes over time, except for deterioration. Again holding true to his conception of monuments, in Algiers Lézine shows most interest in the large mosques and residential palaces. ${ }^{58}$ Though some of these palaces are located within the current boundaries of the Casbah, the idea of preserving an entire urban landscape was not yet conceivable.

This study took place around a tumultuous time of Ben Bella's presidency, making his presence all the more impressive. A small uprising in the east of the country, specifically around Tizi Ouzou, required military action in late 1963 and throughout $1964 .{ }^{59}$ The brief insurrection of the Front des Forces Socialistes, or FFS, points to the deeper issues behind the united Algerian façade. Led by a co-founder of the FLN, Hocine Aït Ahmed, this group stood against Ben Bella whom they perceived to be a fascist dictator. ${ }^{60}$ Staking their identity on one of the three main pillars of post-independence Algeria points to yet another complexity. Ahmed claimed that his brand of socialism was superior to Ben Bella's, though Ruedy notes that socialism was not a rallying factor for much of the middle class. ${ }^{61}$ This was only the first formal opposition group to use a piece of the claimed Algerian identity against the state. Though Ahmed and the FFS were dispatched quickly, as the government tried to gloss over any cracks, they only got worse.

Two years later Lézine returned to Algeria for another mission to study cultural heritage at the request of the government. ${ }^{62}$ In the intervening time, however, that government had changed considerably.

\footnotetext{
${ }^{58}$ Lézine, "Algérie conservation et restauration des monuments historiques," 1964, 11.

${ }^{59}$ Hill, "Identity and Instability in Postcolonial Algeria," 8.

${ }^{60}$ Ruedy, Modern Algeria, 201.

${ }^{61}$ Ibid, 201-202.

${ }^{62}$ Lézine, “Algérie conservation et restauration des monuments historiques," 1966, 1.
} 
In 1965, a bloodless coup led by Houari Boumedienne lead to a new regime. The power shift was announced calmly over the radio, emphasizing the importance of the State over the individual power that Ben Bella valued. ${ }^{63}$ There is an odd calmness to the way the coup is described, suggesting that it was just another simple change in leadership without many consequences. Though this meant less political upheaval, it also meant that despite the idealistic rhetoric of improvement in the 1965 proclamation, much remained the same. Houari Boumediene had been a part of the Armée de libération nationale (ALN), the military wing of the FLN, who ascended to leader of the Armée nationale populaire (ANP, the post-independence re-branding of the ALN), within Ben Bella's regime. ${ }^{64} \mathrm{He}$ is often remembered as a strong president who presided over, and helped concoct, a period of considerable economic growth though to some, he acted to the detriment of society. ${ }^{65}$

For his second study on Algeria in 1966, Lézine again had six weeks. Due to his previous knowledge of the country and guidance by Algerian officials, his scope was smaller, allowing his study to go further in depth. Part of this narrowed scope included the Casbah and its potential preservation at length, as requested by Mr. Baghli, director of museums and historic monuments. ${ }^{66}$ Since this was an on-site report focused on material evidence, Lézine does not investigate the history of the Casbah. In investigating the Casbah, he splits it into three portions, each to be treated separately: the Upper Casbah, the Lower Casbah, and the Marine Quarter. ${ }^{67}$ Each is treated differently due to the various historic value of each. Ultimately the Marine Quarter is essentially ignored for having lost much of its historical fabric. He suggests that the remaining two, differing in their respective amount of historic residences, should have different preservation plans including the term for each type of work. For the Upper Casbah, he suggests a project of restoration while the Lower Casbah will be renovated. ${ }^{68}$

\footnotetext{
${ }^{63}$ Ruedy, Modern Algeria, 207.

${ }^{64}$ Ibid, 194.

${ }^{65}$ James Le Sueur, Between Terror and Democracy: Algeria since 1989 (New York: Zed Books, 2010), 20-21.

${ }^{66}$ Lézine, "Algérie conservation et restauration des monuments historiques," 1966, 24.

${ }^{67}$ Ibid, 25.

${ }^{68}$ Ibid, 29.
} 
One aspect of the Casbah that he does ignore without reason, are the people that live there.

Though he asserts that whatever plan is set in motion, "la casbah doit rester peuplée," ${ }^{69}$ there is no reason to believe that he wanted any of its current residents to stay. He goes on to suggest that the restored Casbah might "attirer une certaine classe d'habitants qui viendraient y chercher le calme si fâcheusement absent de quartiers modernes. ${ }^{, 70}$ Considering that this report was not commissioned by a top level official and considering the subsequent governmental events, it seems likely that this report was shown to Mr. Baghli's superiors and that this report had some impact on the future of the Casbah. Lézine, as a UNESCO consultant would have had significant power behind his words and he speaks highly of the Casbah. In his eyes, "par son caractère unique au monde, la casbah d'Alger appartient au patrimoine culturel de l'humanité tout entière au même titre que les temples égyptiens menacé par les eaux du Nil,",71 referring to the monuments threatened by the construction of the Aswan Dam. Setting the Casbah on the same level as Egyptian monuments could only be encouraging for the Algerian government. It suggests that no matter how large the threat, any and all resources should be used to save the Casbah. To further the value of the site, Lézine lays out further benefits of its potential use as cultural nationalism, including tourism and jobs, easy bait for nearly any government, especially a burgeoning one.

In the meantime, the Algerian government under Boumediene was working to elevate the economy. Abdessalam Belaid targeted hydrocarbons as the natural resource that could potentially offer economic independence for the young country. ${ }^{72}$ Another portion of the plan included nationalization of several important branches of the economy including hydrocarbons. The influential national corporation created to preside over the hydrocarbon sector was SONATRACH. ${ }^{73}$ This nationalization of the economy extended to the construction industry as well. The solidification of power is echoed in the first new law

\footnotetext{
${ }^{69}$ Ibid, 30. Translation: "the Casbah must stay populated"

${ }^{70}$ Ibid, 31. Translation: the Casbah might "draw a certain class of inhabitants whom would come there to find the calm so unfortunately absent in modern quarters."

${ }^{71}$ Ibid, 37. Translation: "by its unique character in this world, the Casbah of Algiers belongs to the cultural heritage of all of humanity in the same way as the Egyptian temples threatened by the waters of the Nile"

${ }^{72}$ Ruedy, Modern Algeria, 217

${ }^{73}$ Ibid.
} 
concerning national heritage in independent Algeria, written in 1967. It brings specific pieces of the urban fabric under direct control of the government, emphasizing a connection between the state and its built history.

This document, published in the Algerian government's Journal Officiel in January, 1968 provides a list of the sites considered National Heritage, revealing the roots of Algerian preservation that reach back to the colonial era. Officially known as ordinance 67-281, it was signed into law on December 20, 1967, building primarily on laws from the French colonial period. The chronology is interesting, considering that two UNESCO surveys had taken place prior to this ordinance. The Casbah as a district is not listed as a national monument, but particular sites within the future perimeter make an appearance. Both the citadel and bastion 23 are listed on their own merit, with their classification dates listed as March 30, 1887 and October 30, 1909 respectively. ${ }^{74}$ Within the ordinance, the meaning of cultural heritage, expands beyond a simplistic idea of 'national monument' used by Lézine in 1964. It is carefully worded to consider both buildings and artefacts including those not yet discovered. Natural sites are also included though they are not of particular interest here. The careful language considers what can and cannot be done with cultural property either by the government or the owner. Attention is given to the relationship between the government and privately owned heritage, especially considering sites that need preservation work. In addition to expected clauses outlawing unauthorized demolition or changes to a site, there are unexpected parts as well. Article 43 suggests that an owner does not necessarily have to maintain the building. It goes on, however, to say that “Pour assurer l'execution de ces travaux, le ministre chargé des arts peut, à defaut d'accord amiable avec ces propriétaires, autoriser l'occupation temporaire des lieux classés ou des immeubles voisins." 75 This occupation time is limited to six months, however, which limits

\footnotetext{
${ }^{74}$ Annex I, Ordonnance 67-281, December 20 1967, Journal Officiel de la République Algerienne, (Algiers, Algeria) January 23 1968, 59. It is also worth noting that all six of the monuments identified by Lézine in his 1964 study are present on this list.

${ }^{75}$ Article 43, Ordonnance 67-281, 1968, Journal Officiel, 53. Translation: "to assure the execution of this work, the minister of arts can, failing an amicable agreement with its owners, authorize the temporary occupation of classified places or neighboring buildings."
} 
the work that could hypothetically be done. Expropriation is another possible choice for the government to make regarding these sites. This option extends to all real estate within the field of visibility from these sites, recognizing the value of a historical view. ${ }^{76}$ It is limited by requiring the expropriation to be for "l'utilité publique," or public utility. This vague phrase is not defined in the ordinance, which leaves it open to interpretation possibly to the detriment of landowners. The only stipulation requires public utility to be declared by the state when a site is set to be expropriated. ${ }^{77}$ The government also claims control over the image of the site with this ordinance. Article 45 prevents any advertisements, even posters, from being placed in or on sites or monuments and in their fields of vision. ${ }^{78}$ Any staged event, photography, or cinematography is also deemed to be under control of the state, according to Article $46 .{ }^{79}$ This control of the images projected by and taken of listed sites co-opts and expands on the 1962 UNESCO "Recommendation Concerning the Safeguarding of the Beauty and Character of Landscapes and Sites," that suggests regulation of advertising and signage. ${ }^{80}$ The control suggested in this recommendation demands formal laws concerning heritage sites. Prior to the Algerian ordinance, the lack of laws surrounding patrimony suggests that, as an element of national building, heritage was not a top priority. Still, it helps to bring together state nationalism and cultural nationalism by bringing these sites under the control of the government in a way that reflects the state-run monopolies of the important sectors that helped solidify political power.

Fueled by the international efforts to save Abu Simbel in the '60s referenced above and severe flooding in both Florence and Venice, the UNESCO World Heritage Convention was created in late 1972. ${ }^{81}$ The 38 article document covers the basic definitions of natural and cultural heritage and lays out foundational rules for the bureaucratic operation within the umbrella organization of UNESCO. It is

\footnotetext{
${ }^{76}$ Article 53, Ordonnance 67-281, Journal Officiel, 53.

${ }^{77}$ Article 54, Ordonnance 67-281, Journal Officiel, 53.

${ }^{78}$ Article 45, Ordonnance 67-281, Journal Officiel, 53.

${ }^{79}$ Article 46, Ordonnance 67-281, Journal Officiel, 53.

${ }^{80}$ O'Keefe \& Prott, eds., Cultural Heritage Conventions and Other Instruments, 222.

${ }^{81}$ Ibid, 77.
} 
careful to include the limitations of listing a site, namely that the responsibility to protect World Heritage will still fall to the country it is located in. This diplomatic stance highlights the difficulties of operating on an international level. The only true benefit of having a site listed, at least at the outset, was the possibility of awareness and international aid in preservation. Section III outlines the creation and operation of the World Heritage Committee, the decision-making group that essentially gives the Convention life. Though it is stipulated in Article 8 that the composition of the committee should "ensure an equitable representation of the different regions and cultures of the world," it does not explain how this should happen. ${ }^{82}$ Considering that it was not certain who would accept the convention, this inclusion seems like an ideal with no true enforcement possible. Indeed, the committee has had difficulty in the past with diversity. ${ }^{83}$ Since the Convention is essentially a skeleton, the Operational Guidelines were created by the Committee at their first meeting in 1977 to effectively qualify the vastly different sites and to add necessary bureaucratic procedure. A site can now be nominated under ten different criteria, six pertaining to cultural sites and four to natural sites. The general vagueness of the criteria allow for sites to claim each one in various ways. Article 12 of the Convention awkwardly references the future criteria with the understanding that not every nomination will take hold. It reads as a sort of consolation for rejected sites stating that exclusion from either the World Heritage List or the List of World Heritage in Danger should "in no way be construed to mean that it does not have an outstanding universal value for purposes other than those resulting from inclusion on these lists." ${ }^{84}$ This awkwardly worded consolation drives home the complexity and difficulty of having a World Heritage List. For all of the attention it raises for cultural diversity and preservation, it gains value from exclusivity. The more sites listed as World Heritage, the

\footnotetext{
82 "Convention Concerning the Protection of the World Cultural and Natural Heritage," UNESCO, November 16 1972, http://whc.unesco.org/en/conventiontext/.

${ }^{83}$ O'Keefe \& Prott, Cultural Heritage Conventions and Other Instruments, 78-79.

84 "Convention Concerning the Protection of the World Cultural and Natural Heritage," http://whc.unesco.org/en/conventiontext/.
} 
lower the value of the designation. A large number of sites holding significant meaning to people should be left off of the list under this idea.

Following the adoption of the World Heritage Convention, 1973 was a busy year for heritage in Algeria. At the behest of the Algerian government, three UNESCO officials went to Algiers in July of 1973 to survey the Casbah and present possible methods of preservation. This is the first survey done that focuses solely on the Casbah. Previous studies of the district by COMEDOR and a seminar held in Algiers in October, 1972 were precursors to this international attention. ${ }^{85}$ The three authors of the report, J. Doulcier, K. Pawlowski, and L. Sato are described as having "leur activité orientée vers l'urbanisme des villes anciennes dans la problématique de leur revalorisation et de la cohérence des choses contemporaines avec le patrimoine architectural et les sites." ${ }^{86}$ This comes across throughout the study in their thorough consideration of possible means of preservation, issues, and necessary steps forward. They begin by identifying the value of the district to Algeria both architecturally and through its ties to the past. The Casbah is "à la fois un témoignage historique et un sujet de pensée très contemporaine. La Casbah est ainsi non seulement un monument historique de grande valeur mais aussi un des ensembles essentiels qui font la personnalité d'Alger passée, actuelle et future. ${ }^{187}$ In no uncertain terms, they link the entire city of Algiers to the Casbah, effectively tying together their fates. If their assessment rings true, if the Casbah were left to deteriorate, so too would the identity of the entire city. Not only do they recognize the worth of the site and its necessary preservation, they go on to say that "La valeur de cet exemple d'urbanisme est ainsi indiscutablement à l'échelle des préoccupations de l'humanité dont l'Unesco est gérante." ${ }^{88}$ Like

\footnotetext{
${ }^{85}$ J. Doulcier, K. Pawlowski, and L. Sato, "Révalorisation de la Casbah d'Alger" (Paris: UNESCO, July 1973), http://unesdoc.unesco.org/images/0000/000066/006627fb.pdf, 1 .

${ }^{86}$ Ibid, 1. Translation: "their activity oriented towards the urbanism of old cities in the issue of their revalorization and of the coherence of contemporary things with the architectural patrimony of the sites."

${ }^{87}$ Ibid, 2. Translation: "at once historical evidence and a subject of very contemporary thought. The Casbah is thus not only a historic monument of great value but also one of the essential ensembles that makes the personality of Algiers past, present and future."

${ }^{88}$ Ibid. Translation: "The value of this example of urbanism is thus indisputably at the level of heritage concerns that UNESCO manages."
} 
Lézine in his 1966 study, these three experts make sure to highlight the level of value that the Casbah has, ensuring a continued interest from UNESCO.

The state of the Casbah is also surveyed in depth, looking at the amount of buildings, their condition, and a rough estimate of the population of the site. They are also careful to explain their definition of the Casbah, which is investigated in two different frames, the "large perimeter" and the "small perimeter." 89 The latter includes only the original tissue of the Casbah while the former extends beyond the protected district. Overall, 1,741 buildings were considered, the overwhelming majority of which were classified as "traditional type." ${ }^{, 90}$ According to the survey, the average family inhabits, on average, 1.6 rooms. ${ }^{91}$ They go on to suggest that this overcrowding might be slowed by asking residents if they mean to stay in the Casbah after restoration and to define what they will contribute to the district. ${ }^{92}$

Preservation is presented here in a way that suggests improvement not only of the buildings but of the living conditions of the site. Yet, the authors show concern that the people would not be amenable to restoration efforts due to the costs and the necessity to leave the Casbah while work is done. To remedy this perceived pushback, the authors suggest that the restorative work be done on a small portion of the Casbah at first to prove the worth of the work. The social improvement of the district is alluded again in this context. They suggest that the smaller focus of work would help open up the Casbah to the rest of the city, ${ }^{93}$ implying that the architectural isolation of the site is one of the basic issues. Though they earlier argue for the maintenance of the traditional role of the Casbah and identify past reactions against the urban system as unfounded, they do not seem to recognize the isolation of the site as a basic trait Yet, it was under the guise of opening up the Casbah that the initial widening of streets was executed in the

\footnotetext{
${ }^{89} \mathrm{Ibid}, 4$.

${ }^{90}$ Ibid.

${ }^{91}$ Ibid.

${ }^{92}$ Ibid, 5.

${ }^{93}$ Ibid, 11.
} 
1830s. The basic traits of the medina cannot be properly assessed in their modern context of European architecture. Only looking at the pre-1830 city could result in any accurate assessment of initial isolation.

Moving forward, the document outlines possible plans for preserving the district based on the idea that it should not be made into a museum but rather to keep its traditional function even while understanding that tourism will be factored in. ${ }^{94}$ Issues identified by the survey include the current overpopulation of the site, its current isolation from the rest of the city, winning over current residents to the planned improvements, rehousing the current inhabitants, and funding for the extensive work. Estimations of rehabilitation cost per house ranged from 40,000 to 200,000 Algerian dinars ${ }^{95}$. In present day US dollars, that same range would go from $\$ 53,866$ to $\$ 269,321 .^{96}$

The study also discusses who should be responsible for the cost of restoration. Considering that most of the buildings in the Casbah were privately owned, they suggest that the responsibility might fall to the owner to rehabilitate the structure. ${ }^{97}$ However, the cost might mean that renters would demand higher rent than the 1973-era inhabitants could afford. They recognize that the majority of the residents of the Casbah were not the residents during French occupation as those families had moved to the French area of the city when the French fled the city. ${ }^{98}$ Though this means that to some extent they are valued less, the study does acknowledge the moral issue of kicking out 50,000 people especially when that likely means moving them from the center of the city to the outskirts. The quality of this survey is evident as several of its ideas remain relevant even today.

\footnotetext{
${ }^{94}$ Ibid, 4.

95 Ibid, 10.

96 In June 1973, 200,000 dinars was worth 50,473 US dollars, according to this date specific currency calculator: http://fxtop.com/en/currency-converter-past.php?A=200000\&C1=DZD\&C2=USD\&DD=17\&MM=06\&YYYY=197 $\underline{3 \& \mathrm{~B}=1 \& \mathrm{P}=\& \mathrm{I}=1 \& \mathrm{btnOK}=\mathrm{Go} \% 21}$. Adjusting for inflation, 200,000 dinars in 1973 is equal to about $269,321 \mathrm{US}$ dollars today, according to this inflation calculator: http://data.bls.gov/cgi-bin/cpicalc.pl?cost $1=50473 \& y e a r 1=1973 \& y e a r 2=2016$. Using the same methods, the lower estimate of 40,000 is equivalent to 10,095 US dollars in 1973, or 53,866 US dollars today.

${ }^{97}$ J. Doulcier, K. Pawlowski, and L. Sato, "Révalorisation de la Casbah d'Alger," 13-14.

${ }^{98}$ Grabar, "Reclaiming the City," 396.
} 
While the UNESCO survey was underway in July, President Houari Boumediene signed ordinance 73-38 ratifying the World Heritage Convention. ${ }^{99}$ Published in the Journal Officiel on August 28 , the quick acceptance of the international document ${ }^{100}$ signals further and significant political interest in the idea of World Heritage. The Convention offered a new potential platform to showcase the Algerian identity that was so carefully constructed. As Jarzombek says, this initiative would bring together the cultural and state nationalism and elevate it to an international level.

In November of 1973, the process to declare the Casbah a site of National Heritage was finally enacted. As dictated by Ordinance 67-281, after the announcement in the Journal Officiel, there would be a period of two months for owners of buildings within the Casbah to raise their concerns. In agreement with Article 28 of Ordinance 67-281, discussed above, the classification was not enacted by the various proprietors but rather by the government, suggesting further that the Casbah was a site of considerable governmental interest. Recognizing it as a valuable site of cultural nationalism, expanding the legislative framework around it would bring it as well into the fold realm of state nationalism. Though the process began with this document, it seems that the Casbah was not considered a protected heritage site until 1991.

The National Charter and Constitution of 1976 offers insight into the identity that Boumediene envisioned for Algeria. Boumediene reaffirms the same identity markers set in place by Ben Bella though, as Hill highlights, socialism is elevated to a driving element at the heart of Algeria via the Cultural Revolution that he champions. ${ }^{101}$ A draft of the National Charter was presented to the people for them to criticize in 1976. This move was meant, by Boumediene to be a move towards democratization, though

\footnotetext{
${ }_{99}$ Ordonnance 73-38, July 25 1973," Journal Officiel de la République Algerienne, (Algiers, Algeria) August 28 $1973,805$.

${ }^{100}$ Yet, according to UNESCO, Algeria did not ratify the convention until June 24, 1974. There are no corresponding publications in the Journal Officiel to explain the discrepancy though it may be possible that the first announcement was only foregrounding the issue and that actual ratification came nearly a year later though it was not explicitly announced yet the function of the Journal Officiel as described here, would be to circulate already accepted items.

${ }^{101}$ Hill, "Identity and Instability in Postcolonial Algeria," 9.
} 
little was changed in the final document. ${ }^{102}$ Socialism as the economic model, the FLN as the sole political party, and the hydrocarbon sector as the main interest of the government are all reiterated in the final document. ${ }^{103}$ Importantly, it also offered women equal status under the law. Though it exemplifies entrenchment in the expected affirmations of the state, the advancement of women's rights suggests that within that basic framework, progress could be made.

The first World Heritage Committee meeting was held between June 27 and July 1, 1977. Though Algeria had ratified the World Heritage Convention, no delegates from the country were present at the meeting. The delegates present did represent a wide variety of states, however, including Iraq, Iran, Ghana, Tunisia, Egypt, Nigeria, and Ecuador in addition to the expected Western powers. ${ }^{104}$ Essentially, the meeting uses the World Heritage Convention as a base document to expand upon. The World Heritage List originated in this meeting, though some of the earliest sites have their inscriptions listed as 1972.

Both scope and depth improve in the 1978 study of the Casbah, the most in-depth survey of all. Interconnectedness is a multivalent theme throughout this report. It refers not only to the necessary inclusion and teamwork of several different specialists, but the interdependence of the structure of the houses as well. The 82 page document includes observations, recommendations, and a brief plan of action. In terms of recommendations and observations, they are far more in depth than previous studies. This increased interest suggests a desire to enact these plans rather than continuing to commission studies. Indeed, one of the prescriptions includes recurring visits, yet they are suggested to be short, designed to check in on progress rather than dictate it entirely. The length of this visit (four months) and the size of the team (five members) allows the study to reach these new depths. Infrastructure is a new element of intense focus here that is considered in its current state as well as its potential future. Dealing with the difficult realities of the sewers, potable water, gas, and electricity, the plan looks at mitigating the

\footnotetext{
102 James Ciment, Algeria: The Fundamentalist Challenge (New York: Facts on File, Inc., 1997), 44.

${ }^{103}$ Le Sueur, Between Terror and Democracy, 24.

${ }^{104}$ Annex I, “World Heritage Committee First Session” (UNESCO, June-July 1977).
} 
difference between retaining authenticity while bringing the Casbah into the modern era, a balance that was echoes the initial assimilationist sentiment of the French though with the important addition of cultural sensitivity, improved technology, and further developed preservation theories. It is understood from the introduction, as in previous studies, that the site should be treated "non comme un musée, mais une partie intégrante et homogène de la ville moderne d'Alger." ${ }^{105}$ Ultimately, the compromise comes in understanding that those living in the Casbah cannot be expected to live like it is still the sixteenth century, even if the architectural style speaks of that era. Previously, modernization of the Casbah had meant "la transformation des trous d'éclairage et de ventilation en grandes fenêtres et la démolition des encorbellements et des niches pour construire un mur de façade possédant des fenêtres de plus grandes dimensions." ${ }^{106}$ Here it is suggested that architectural style can be maintained while improving the comfort of inhabitants, primarily through improved infrastructure. They consider the colonial period as a tragic mistake that compromised the impressive dense fabric and, as such, any future work must recognize the importance of the historical style. The strong rejection of the colonial period and hints at reversing its effects, however, point to a larger preservation issue. While the complex history is clearly understood, the change enacted during the colonial period is seen as a detraction from the whole rather than an integral piece of its story. It is a similar to larger Algerian history that "was fundamentally shaped by the country's colonial experiences." ${ }^{\prime 107}$ The French period was critical not only for Algerian identity but for its physical structuring as well, a point that should not be erased or ignored.

The report ultimately recognizes the importance of the Casbah as more than a cultural or historic site of interest, but a critical piece of a living city in the midst of massive urbanization. In the Introduction they reference the housing policy of the Algerian government, designed to provide decent housing for all,

\footnotetext{
${ }^{105}$ Dorothée Vauzelles Barbier et al., "Mission d'Assistance préparatoire Revalorisation de la Casbah d'Alger" (Paris: UNESCO, 1978), http://unesdoc.unesco.org/images/0003/000321/032150fb.pdf, 1. Translation: "not as a museum, but as an integral and homogeneous part of the modern city of Algiers."

${ }^{106} \mathrm{Ibid}, 6$. Translation: "the transformation of holes for lighting and ventilation with large windows and the demolition of cantilevers and niches for the construction of a façade wall possessing windows of larger dimensions." ${ }^{107}$ Hill, "Identity and Instability in Postcolonial Algeria," 1.
} 
and its relation to preservation. The primacy of the Casbah in the center of the capital relates to its overpopulation. The population is quoted as 100,000 people in 1,750 houses, or roughly 57 people per domicile. ${ }^{108}$ This alarming number is high, even in the context of the larger urbanization crisis estimating "9.5 individuals occupied each unit of housing." 109 Preservation would not only bring vital services to the site but bring the population of the Casbah under control.

While the 1973 study critically considered the logistical issue of rehousing residents, completing work, and facilitating a depopulation of the Casbah, the more pressing issues here are the actual logistics of completing the needed work. While the difficulty was recognized previously, here more fleshed out potential solutions are offered, though still in a very schematic form. One image shows a system for lifting pieces into the heart of the dense urban fabric that takes away the problematic narrow and winding streets recognized as a problem in the 1973 study. (Fig. 15) The solution uses the wide streets driven through the district by the French to their benefit, creating towers in each to create a cable system to transport materials up the steep grade. Despite the cartoonish representation, the image presents real ideas that have progressed beyond talk.

Two of the annexes to the report are of particular interest. The first focuses on the legal framework for preservation in Algeria, mentioning ordinance 75-22 dealing with the planning of Algiers, and several smaller laws. This annex speaks to the depth of the study and its gravity. It is followed by a second annex that lists all of the individual sites within the Casbah that are listed as National heritage under ordinance 67-281, discussed earlier. The twenty-five separate listings include fountains, doors, and single houses as well as groups, such as Bastion XXIII. Such an extensive list drives home the value of treating the Casbah as a singular subject rather than several separate pieces of varying importance. Coupled with a look at the various laws, it also suggests that treating this large, problematic area as a single entity may make its administration simpler.

\footnotetext{
${ }^{108}$ Dorothée Vauzelles Barbier et al., "Mission d'Assistance préparatoire Revalorisation de la Casbah d'Alger," 4.

${ }^{109}$ Ruedy, Modern Algeria, 236.
} 
Following the theme of simplicity, 1978 also marked a shift in focus to a specific piece of the Casbah, despite the potential benefits of treating it as a singular site. The Algerian Ministry of Culture and Tourism began commissioning studies on the potential rehabilitation of the Citadel alone. There are two potential ways to understand the downsized interest represented by this choice. The first sees the Citadel as a more manageable site with less complications than a whole district. A more positive view of the choice considers the smaller scale to be a test run for future preservation of the district, a variation on the suggestion from the 1973 study. Both perspectives speak to the difficulty of preserving the Casbah that is continually expressed through these various studies. The perseverance of authorities pursuing its preservation, however, only solidifies the importance of the Casbah to the country.

At the end of 1978, Houari Boumediene died of a rare blood disease, leading to yet another political shift. Chadli Benjedid won the election in February 1979, though it is important to note that he had no opposition at all. ${ }^{110}$ Again, though the power shift appeared to be even less contentious than the 1965 coup, issues still erupted that demanded a strong response in the same vein as his predecessors. On a brighter note, taking power in 1979 was fortuitous as the economy was lifted by the rise in oil prices caused by the 1979 Iranian Revolution. ${ }^{111}$ In the fall of 1979, issues with the weak policy of Arabization led Arabic-speaking students to strike for two months in protest against the favoritism shown to French-speaking students. Benjedid, concerned that Islamic Fundamentalists would flock to the cause, acted quickly to advance the Arabization of the government and education. ${ }^{12}$

As fragmentation in the constructed Algerian identity grew more evident, the cohesion of the Casbah was also questioned. Despite the amount of work done considering the Casbah as a complete entity, the government opted to nominate only a portion of it for inscription on the World Heritage List. In 1979 a nomination was submitted to UNESCO for the Palace of the Dey. This brief report gives credence

\footnotetext{
${ }^{110}$ Hill, "Identity and Instability in Postcolonial Algeria," 9.

${ }^{111}$ Ciment, Algeria: The Fundamentalist Challenge, 51.

${ }^{112}$ Ruedy, Modern Algeria, 239-240.
} 
to Lézine's initial findings in 1964 that considered individual structures within the Casbah more interesting than the whole. The justification for the nomination relies on the age and style of the buildings as well as a cultural component. It relates back to both the Ottoman and French periods through these statements of universal value, claiming that its construction began as "the country entered upon a new phase of its history." 113 The palace is also noted to be "of outstanding historical interest" because it is "where the famous 'fly-whisk' incident occurred..." ${ }^{114}$ With a far smaller area, there is far less to worry about as evidenced by the short document. The history section takes up the most room while even the diagnosis of existing problems is short and full of common sense issues, such as "exposure to the weather." 115 Its management would also be considerably easier not just because of its size but because of its ownership and clearly delineated management. Rather than belonging to several different citizens, the Palace is designated in the document as an unoccupied public space, recognized as an Historic Monument and managed by the Director of Museums, Archaeology, and Historic Monuments. The decision to nominate a portion rather than the whole speaks to the difficulty of preservation and a desire to avoid complexity. This may speak to an estimation of what the government could do rather than denial of the importance of the rest of the Casbah, so the decision should not be judged necessarily as an odious decision.

The next year, 1980, saw reactions against the homogenization of Arabization measures enacted within the past year. This time the issue went further than a simple dichotomy between French and Arabic. Since referred to as the 'Berber Spring,' it involved calls for the Berber language Tamazight to be recognized as an official Algerian language. ${ }^{116}$ As mentioned before, the Berbers are considered to be native Algerians, so while the identity espoused by the government did acknowledge pre-colonial history

\footnotetext{
${ }^{113}$ Republic of Algeria, "Convention Concerning the Protection of the World Cultrual and Natural Heritage Nomination Submitted by the Democratic and Popular Republic of Algeria: Dey's Palace" (Republic of Algeria, April 1979), http://unesdoc.unesco.org/images/0003/000378/037826eb.pdf, 4. 
to some degree, it ignored the longer, complex history that might complicate the demographic reality.

This use of history echoes the careful consideration of the built environment. That same year the Palace of the Dey nomination for the World Heritage List was deferred, another rejection of a simple view of history. Before the deferral, however, focus shifted back to the entire Casbah again with yet another study in the summer of 1980. Signaling a shift in interest, the scope of the document only considered the legal framework in Algeria that affected the Casbah and how laws might be written to facilitate preservation. It is essentially an extension of Annex A in the 1978 report that listed relevant legislation. The author of the study had only a week to complete his work, and only had time to meet with the director of l'Atelier de la Casbah and not the more senior Minister of Urbanism, Construction, and the Habitat. ${ }^{117}$ Ultimately, the findings consider the legal framework inadequate to protect the Casbah. Even the governmental structure is criticized indirectly as the author suggests that the new legislation would need to "désigner les autorités ou organos responsables des phases de l'opération de réhabilitation." 118 The strength of the government had consistently been highlighted in the post-colonial era with a plethora of new organizations systematically taking control of important sectors. In the context of preservation, however, a blind spot in the system is revealed.

The final critical moment in 1980 was the designation of Al Qal'a of Beni Hammad as Algeria's first piece of World Heritage. It is important to recall that this site is one of those mentioned by Alexander Lézine in his 1964 report on Algeria as a critical cultural heritage site. Its acceptance and the deferral of both the Dey's Palace and the Setif Citadel suggests either a preference for non-urban sites further removed from colonialism to better represent Algerian heritage or a recognition that preservation in the urban context would not succeed with the specified plans. In 1981, the nomination for the Dey's Palace was pulled from consideration with the intention "to extend it to cover the whole of the Casbah," noting

\footnotetext{
${ }^{117}$ H. Saba, "Mesures légaslatives afférentes à la Casbah d'Alger" (Paris: UNESCO, June 1980), http://unesdoc.unesco.org/images/0004/000406/040619fb.pdf, Preamble \& 7.

${ }^{118}$ Ibid, 8. Translation: "to designate the authorities or organizations responsible for the phases of operation and rehabilitation."
} 
that "this revised nomination would be submitted when the necessary preparatory studies had been completed."119 Here, the shift back to the Casbah is explicitly stated though it interestingly suggests that the amount of surveys done up to that point did not offer enough information to complete a nomination. Considering the studies collected and described above, it seems unlikely that this statement is entirely true. The lack of documentation on the Casbah in the 1980's bolsters this conclusion. It is more likely that removing the nomination was a stalling maneuver to write a more powerful nomination in the meantime. A year later, the World Heritage Committee inscribed five Algerian sites on the World Heritage List: Djémila, M'Zab Valley, Timgad, Tipasa, and Tassili n’Ajjer. ${ }^{120}$ Again, recalling Lézine's 1964 report on Algeria, Timgad, an Ancient Roman site is mentioned as a particular site of interest. Concerning the others, they are respectively, an Ancient Roman site, ${ }^{121}$ a collection of traditional desert ksour, ${ }^{122}$ a Punic and Roman settlement, ${ }^{123}$ and a prehistoric site. ${ }^{124}$ The variety evident in these five speaks to the longer, complex history of Algeria. As stated before, each of these sites is firmly tied to the past, free of any issues of fitting these sites into a larger urban context or the struggle of interpreting a still living site.

As the World Heritage Sites began to describe an Algerian identity on an international stage, a significant challenge to the FLN hegemony was founded. The Front Islamique du Salut (Islamic Salvation Front, or FIS), . As discussed previously, the solidification of a homogenous identity espoused by the first three Algerian Presidents led to disruption by those who did not agree with that identity. Like the FFS before it, the FIS staked its own identity on another one of Algeria's three identity markers, Islam. Of course, as shown previously, the separation of the three was not a simple and issues often crossed lines. Religion and language, for example, were very closely related. The rise of Fundamentalism in the 1980s is well-expressed through the drafting and passing of the Family Code in 1984. Exposing cracks in the

\footnotetext{
119 "World Heritage Committee Fifth Session” (UNESCO, October 1981).

120 "Algeria," UNESCO, http://whc.unesco.org/en/statesparties/dz.

${ }^{121}$ Eric Delpont, Djamila Chakour, and Yannis Koïkas, eds., L'Algérie En Héritage, Art et Histoire, $143-147$.

122 Ibid, 240.

123 Tipasa, http://whc.unesco.org/en/list/193.

${ }^{124}$ Eric Delpont, Djamila Chakour, and Yannis Koïkas, eds., L'Algérie En Héritage, Art et Histoire, 77.
} 
national identity again, women are placed in opposition against Fundamentalists. Though the National Charter in 1976 offered women an equal place in Algerian society, that position was threatened as early as 1979. ${ }^{125}$ A first draft in 1981 was successfully rejected with the opposition of famous women of the Revolution, but ultimately the government sided with the Fundamentalists for political gain. The political maneuver was meant "to make room for this new movement [the Fundamentalists] under the umbrella of FLN leadership." ${ }^{\prime 26}$ The Family Code passed in 1984 was even more conservative than the 1981 draft $^{127}$, a testament to the rising power of the Fundamentalists in Algeria and a shifting identity.

The 1985 UNESCO report on the Citadel primarily investigates the various studies done in 1980 and analyzes the on-going work at the site. It is more of a check-up than a survey like the previous reports. Even in the recommendations for the future, it does not speculate on potential plans or studies but rather suggests regular meetings to keep all different specialists updated on the status of the work. ${ }^{128}$ In this way, it recognizes the interconnectivity highlighted in the 1978 report, though it is on a smaller scale. Working with the government and its smaller subsections, like ARC (l'atelier de restauration de la Citadelle d'Alger), the study is supposed to be the beginning of the phase designed to create the final project. ${ }^{129}$ The report brings to light the work being done on the ground that appears to be the first significant step towards preserving the site. Beyond studies, actual work is evaluated as well. For example, "provisional protection" of shoring and sealing was completed between june and september of 1984. ${ }^{130}$ Most of the highlighted reports took place in the fall and winter of 1980, after the initial nomination was presented to UNESCO but just before the site was deferred. At the time of the study, however, the nomination had been pulled, and focus had supposedly shifted back to the Casbah as a complete entity. In this context, this report should be read as an evaluation of preservation work done on a

\footnotetext{
${ }^{125}$ Ciment, Algeria: The Fundamentalist Challenge, 44, 47.

${ }^{126}$ Ibid, 48.

${ }^{127}$ Ibid.

${ }^{128}$ Alain Bouineau, "Citadelle d'Alger: Expertise des travaux de protection provisoire et des travaux de restauration proposés" (Paris: UNESCO, June 1985), http://unesdoc.unesco.org/images/0006/000667/066735fo.pdf, 27.

${ }^{129}$ Ibid, 1.

${ }^{130} \mathrm{Ibid}, 11$.
} 
portion of the Casbah, like the test section suggested in the 1973 study. The denial of portions of history does suggest, however, that a denial of historical complexity is another driving factor. Concerning identity, a desire to erase the colonial period is present again in the preservation choices "qui reconstitue la Citadelle avant la période française."131

In October 1988 the national discontent exploded in nationwide riots larger than previous ones. The chaos resulted in military action sanctioned by the government that killed at least 200 people and injured far more. ${ }^{132}$ The people involved in the unrest included young unemployed people, fundamentalists, and workers generally frustrated with the state of the government. ${ }^{133}$ With such a clear statement against the government, Benjedid understood that he had to change something, even if only superficially. February 1989 saw a new constitution that removed socialist rhetoric and introduced a multiparty system, leading to the legalization of the FIS. ${ }^{134}$ Announcing their views and policies in March of that year, the new political party also included their interest in the "safeguarding of the Islamic historical and civilizational heritage." ${ }^{135}$ This is a curious inclusion that only solidifies the importance of a material past in creating a new identity.

Significant victories in the municipal elections of June 1990 allowed the FIS to gain political experience to back up its rhetoric. Their competent governance added strength to their party as a potential threat to the FLN. Distrust in the FLN that was exacerbated by their response to the October 1988 riots only grew when the French government showed support for the FLN. ${ }^{136}$ Internationally, the Gulf War presented a political minefield, particularly for the FLN. Ultimately, the government took a neutral position that the FIS spun into an anti-Islamic statement. ${ }^{137}$ The FLN, however, saw the FIS support for Hussein as negative point and enacted a couple of policies to stack the cards in their favor for the 1991

\footnotetext{
${ }^{131}$ Ibid, 2. Translation: "...that reconstructs the Citadel before the French period..."

${ }^{132}$ Ciment, Algeria: The Fundamentalist Challenge, 52.

133 Ibid.

${ }^{134}$ Ibid, 53.

${ }^{135}$ Ruedy, Modern Algeria, 252.

${ }^{136}$ Ciment, Algeria: The Fundamentalist Challenge, 56.

${ }^{137}$ Ibid.
} 
parliamentary elections. First, they moved the elections forward to June. ${ }^{138}$ Districts were then gerrymandered to theoretically support the FLN. ${ }^{139}$ In response to these actions, the FIS called for a general strike at the end of May ultimately leading to the government cancelling elections and enacting martial law. Eventually, the elections were rescheduled for December, with changes made to the FLN policies that initially caused unrest. In the midst of these serious political issues, the Casbah was nominated for the World Heritage List. As a site with critical national history relating to the Revolution, whose importance to the city and country has been reiterated throughout these documents, it is difficult to believe that the timing was coincidental, or that this news had no effect on citizens.

The ICOMOS Evaluation prior to designation is dated November, 1991, meant to help inform the decisions made at the World Heritage Committee meeting that year (9-13 December, 1991). Two major concerns are addressed in the small report, first the dedication of authorities to preservation of the site, and second, its relation to other Maghrebian medinas. Considering the political climate of the time, a concern for government stability makes sense, and yet, the complaint was removed after a letter from the Algerian delegation convinced the ICOMOS representatives that they were committed to preserving the Casbah. ${ }^{140}$ The latter complaint seems to be motivated by a sense that the French colonial period marred the authenticity of the site. This idea has recurred throughout the documents presented in this chapter, though here it threatens its designation as World Heritage. Again it chooses a particular moment of purity in its history to give it value, particularly the Ottoman period, saying that it will stand "as an outstanding example of an historic Maghreb city with specificities related to the natural site and history of the city despite the destructions due to poor preservation of the ancient urban fabric." ${ }^{141}$ It is unclear if the "destructions" ICOMOS refers to are the large interventions enacted by the French or if it is pointing to a lack of care under the Algerian government. Ultimately, what matters is the affirmation by ICOMOS that

\footnotetext{
${ }^{138}$ Le Sueur, Between Terror and Democracy, 47.

${ }^{139}$ Ciment, Algeria: The Fundamentalist Challenge, 56.

140 “World Heritage List No. 555" (ICOMOS, November 1991), 1.

${ }^{141}$ Ibid, 3.
} 
the Algerian cultural identity has little to do with the French period, just as suggested by governmental policies. Despite the misgivings expressed by ICOMOS, at the World Heritage Committee meeting in December the process to inscribe the Casbah on the World Heritage List began.

Interestingly, it was not until November 24, 1991 that the Casbah was officially declared a National heritage site. Decreed and published on the same day in the Journal Officiel, the timeline is already strange. In a larger context, the timing is even stranger. Recalling the 1973 decree that appeared to classify the Casbah as a National Heritage site, it seems odd that this decree is also necessary. It is even stranger that the 1973 decree is referenced in this new decree. Also odd is the relationship to the ICOMOS concerns and impending decision regarding its World Heritage nomination. With all of these oddities, it is unlikely that this decree was not politically motivated.

While the Casbah was recognized as a site of Outstanding Universal Significance, the climate back in Algeria soured as the December parliamentary elections proved catastrophic for the FLN. The FIS won outright in significantly more districts than the FLN, who came in third behind the FFS. For the districts that were not decided by the first vote, a runoff between the top two candidates was scheduled for January 18,1992 . Internally, the FLN was divided in their reaction. Benjedid held that as president he would be able to block any action of the FIS-controlled parliament. Others were more pessimistic and considered the prospect that the FIS might attain the two-thirds majority necessary to change the constitution something to avoid at all costs. On January 11, one week before the second round of elections, Chadli Benjedid was forced by the military to resign as president of Algeria, and dissolved parliament. ${ }^{142}$ Unlike the past power shifts considered in this chapter, a fragmented and discontent population coupled with political turmoil could not be overcome by the same nation building techniques of Ben Bella, Boumediene, and Benjedid. Benjedid's void was filled by the High Security Council only three days after his resignation and they immediately dismissed the December elections and their

\footnotetext{
${ }^{142}$ Le Sueur, Between Terror and Democracy, 51.
} 
subsequent runoff. ${ }^{143}$ To run the government, they created a five-person council, the Haut Comité d'Etat (HCE) ${ }^{144}$ By March, the leader of the FIS had been arrested, the FIS banned, and a state of emergency had been declared. ${ }^{145}$ The man recruited to act as the President of the HCE was Mohamed Boudiaf, an original founder of the FLN who had been exiled in Morocco since the 1960s. This attempt to play to the revolutionary roots of the party was another move that proved just how deaf the government was to the prevailing perspective. This did not mean, however, that the narrative of the Moudjahidin was gone, it was only spun in a different direction. Those in power were understood as false Moudjahidin and in the narrative the real revolutionaries never felt the benefits of power. ${ }^{146}$ This is echoed by the response of the FIS after the coup, calling out to "...all those who love Algeria to take a stand against this oppressive clique of foreign agents that has usurped power." ${ }^{147}$ An initial calm after the coup was broken when, just after the state of emergency was declared on February 9th, six police officers were killed in the Casbah. ${ }^{148}$ On June 29th, the short presidency of Boudiaf ended when one of his own guards shot him in the back while giving a speech on national television. ${ }^{149}$ Of course, with the HCE in power there was no true power vacuum following Boudiaf's death but the country remained in turmoil. At the end of August the Algiers airport was bombed. Three months later curfews were enacted in several areas including Algiers. Amidst all of this, the Casbah was officially inscribed on the World Heritage list in December. The preservation issues outlined in the UNESCO documents and discussed here would now accompany a tumultuous political landscape that often translated into terror.

Over the thirty years discussed here, in government and international documents, the political use of cultural heritage as an element of nation building can be seen. It was an early interest that transcended

\footnotetext{
${ }^{143}$ Ciment, Algeria: The Fundamentalist Challenge, 58.

${ }^{144}$ Le Sueur, Between Terror and Democracy, 51.

${ }^{145} \mathrm{Ibid}$.

${ }^{146}$ Luis Martinez, The Algerian Civil War 1990-1998, trans. Jonathan Derrick (London: Hurst \& Company, 2000), 41.

${ }^{147}$ Quoted in Ciment, Algeria: The Fundamentalist Challenge, 171.

${ }^{148}$ Ciment, Algeria: The Fundamentalist Challenge, 172.

${ }^{149}$ Le Sueur, Between Terror and Democracy, 59-60.
} 
power shifts and turmoil. In relation to an international understanding of preservation, the Casbah represented several challenges. As a large, urban site with a living population, its preservation issues were different and often more complex than those of traditional monuments. The complexity of the Casbah echoes the intricate identities of the Algerian population that transcended the simple arab, muslim, socialist identity repeated over these thirty years. The refusal to recognize French interventions as a critical part of the fabric demonstrates a desire to deny the French period any recognition while linking to a more explicitly Algerian past. While the mitigation between the past and present has been largely theoretical throughout this chapter, the next will venture into the realities of bringing the two together. 


\section{III: World Heritage as an International Image}

On December 7, 1992, the streets of the Casbah did not change. Far off in Santa Fe, USA, the site was inscribed on the UNESCO World Heritage List but even the next day, this supposedly important moment had done nothing for the people living in the overcrowded district in the midst of a Civil War. It was listed under criteria ii and v, valuing its traditional architecture and settlement, while rooting it in a pre-French colonial past. Considering this difficult environment, it is necessary to question the inscription and its timing. Due to its acceptance in 1991 but delayed inscription, the process is referred to by an ICOMOS representative in 2003 as "following a somewhat unusual procedure."150 Recalling that the 1991 meeting was held just before the disastrous and contentious parliamentary elections, the conditional acceptance rather than deferral may speak to an attempt to support the Algerian government in trying times. Since the Casbah had been a symbol in the fight for Independence and tied to the Moudjahidin and the FLN, its rise to international fame strengthens the ties between government and site, at least in symbolic terms. The politics behind the process are again evident in comments considering the nomination. In 1991 the ICOMOS review of the Casbah was changed at the request of the French Delegation "so that historic events may be correctly portrayed."151 The portion removed is described in the document as a "statement beginning with 'the French occupation...' and ending with 'saved a part of the city." "152 Since the original statement is unknown, no definite conclusions can be drawn beyond an understanding that the history of the Casbah is a contentious subject that can be fought over in diplomatic meetings as well as on the street. Above all, these two examples highlight the complexities of bureaucracy that inevitably spawns the criticism that is the focus of this chapter.

The deterioration of the Casbah has continued in the twenty-four years since its designation as a World Heritage Site while a similar entropic force has worked on the World Heritage program itself,

\footnotetext{
150“'State of Conservation: Kasbah of Algiers," 2003, http://whc.unesco.org/en/soc/2727.

151 “World Heritage Committee Sixteenth Session" (UNESCO, December 1992), 36.

152 Ibid.
} 
resulting in a considerable amount of criticism from the preservation world. Perhaps the loudest and most famous of these voices is Rem Koolhaas, the famous architect who has recently delved into the preservation world both in theory and practice. ${ }^{153}$ His radical view of preservation perceives it as a united, growing empire. ${ }^{154}$ It is positioned in direct opposition to new construction, a force that can highlight or erase history as seen fit. His interest in the broader, theoretical picture of preservation glosses over some major issues even while noting other valid points. Though many others agree that preservation has a power over history, the united front that Koolhaas suggests works counter to the nationalism that is often coupled with preservation, even at an international level. A united empire of preservation does fit well, however, with Michael Di Giovine's idea of a "Heritage-scape," the international cultural history of mankind as curated by the World Heritage Committee. ${ }^{155}$ Mark Jarzombek, despite his belief that preservation stems from nationalism, also manages to provide a rather positive outlook on preservation, suggesting that it has empowered architecture and brought it to the forefront of the arts. ${ }^{156} \mathrm{He}$ does, however, offer some criticism for UNESCO, particularly in their representation of World Heritage sites. More critical, however, are the critiques coming from Lynn Meskell and William Logan, who offer more criticism for UNESCO and their idealistic program. Meskell directly takes on the Statement of Conservation Report as a way to understand the blatant nationalist politics that have permeated this extra-governmental organization. She describes negative SOC reports being ignored for political reasons based on a shift in interest. More bureaucrats are making their way into delegations, driving decisions for many reasons besides preservation. Though Logan acts as a UNESCO apologist for much of his chapter due to this intergovernmental status of the organization, he pinpoints a number of issues within the system as well. For him, the inability of UNESCO to force states into action excuses them from any blame.

\footnotetext{
${ }^{153}$ His firm is currently involved in the work on the prominent Fondaco dei Tedeschi in Venice where in 2011 his Biennale exhibit transformed into a manifesto against the World Heritage Convention.

${ }^{154}$ Rem Koolhaas, "Cronocaos," Log 21 (Winter 2011): 119-23.

${ }^{155}$ Michael Di Giovine, The Heritage-Scape: UNESCO, World Heritage, and Tourism (Lanham, MD: Lexington Books, 2009).

156 Jarzombek, "The Metaphysics of Permanence - Curating Critical Impossibilities."
} 
Instead, he suggests that the states parties are to blame for the blatant nationalism that is threatening the integrity of the program. The concerns of politicization will be explored through the plethora of SOC reports created for the Casbah.

First, it is critical to understand the state of Algeria in the 1990s. Though the origins of the Civil War ${ }^{157}$ can be understood through the political clash of the secular FLN and the religious FIS, it is reductive to view the entire conflict as a solely religious conflict. As shown in the last chapter, social and economic issues were just as critical in setting up the Civil War. This complexity is reflected in the cast of characters on either side of the conflict. Luis Martinez ${ }^{158}$ is able to paint a picture of the conflict by focusing on the human aspect of the struggle as he zeroes in on a specific locale, Les Eucalyptus. The relationship of this community to the Casbah is actually rooted in issues of preservation. Just as relocation communities were suggested in the 1973 UNESCO report, Les Eucalyptus was a poorly built area twenty kilometers out of the city center for Casbah residents in failing houses. ${ }^{159}$ (Fig. 16) Martinez describes the complex spatial dynamics of the Civil War with Les Eucalyptus as a case study. Essentially, just as the FIS and other groups came together on the same side in the October 1988 riots, here as well multiple groups with different motivations were seemingly on the same side against the government. A general sense of lawlessness pervades the period, with petty criminals gaining importance in the environment. Eventually the level of crime advanced to the point that the government no longer seemed to be the true enemy. Instead, the real victims were the ordinary people who did not side with the FIS or with the more localized crime groups. There was a general sense of attrition against these unaffiliated parties, forcing them to choose a side or have no protection against other groups. ${ }^{160}$ In the larger context, faced with uncontrollable but confinable areas, the military left these locations in isolation to wallow in its own

\footnotetext{
${ }^{157}$ It is still argued whether or not "La décennie noire" should be considered a Civil War or not. Martinez's discussion of the war as a conflict that forced people to take sides is a convincing argument that it can and should be considered in such serious terms.

${ }^{158}$ The Algerian Civil War, 1990-1998 is written under a pseudonym due to the danger the author would face if his name were revealed. This is not uncommon, even for fiction authors such as Yasmina Khadra.

${ }^{159}$ Martinez, The Algerian Civil War 1990-1998, 34.

${ }^{160} \mathrm{Ibid}, 74$.
} 
crime without allowing it to spill out into the rest of the country. ${ }^{161}$ The policy of containment, as applied to the Casbah in the War for Independence was thus translated to the country at large. Within Algiers proper, the two most volatile areas were the working class districts of the Casbah and Bab El-Oued. ${ }^{162}$ Just as the myth of the moudjahidin had been reworked by the anti-government forces to sever the revolutionary link of the FLN, the importance of the Casbah in the War for Independence was equally inaccessible to the government.

After inscription, the most critical documents are the State of Conservation reports, prepared as often as deemed necessary by the World Heritage Committee in accordance with the Operational Guidelines. More or less, they act as a conversation between the State Party and the World Heritage Committee. Evidence of this conversation remains one-sided as the only documents available are the recorded responses of the Committee and ICOMOS. ${ }^{163}$ The information included in these responses is useful, however, not only to shed light on the SOC report itself, but the treatment of the property by UNESCO. Though the memory of the Casbah was not a viable political tool for the government within the nation, the SOC reports prior to Abdelaziz Bouteflika's presidency suggest politicization at work.

UNESCO cannot force Algeria to do anything. The committee can only make suggestions and 'strongly urge' action. The Casbah in particular has a significant amount of SOC reports to examine. Over its 24 years on the World Heritage list, it has State of Conservation reports for 13 of them. Of the 20 sites inscribed in 1992, the Casbah is tied for the second most SOC reports, only Angkor has more (16). Looking at the progression of the documents, they paint the picture of a declining site and frustration at the lack of progress and answers. Four successive SOC reports date from the 1990's, the critical years of the Civil War in Algeria. The account of early SOC reports for the Casbah read as decidedly diplomatic and appreciative of the Algerian efforts at preservation. They are all brief; the longest comprises two

\footnotetext{
${ }^{161}$ Ibid, $73 ; 84$.

162 Ibid, 108.

163 Beginning in 2015, more transparency has been built into the World Heritage Committee meetings. They are now open to the media and accessible to the general public on Youtube.
} 
paragraphs. This brevity is not an attribute of SOC report in the early 1990s but rather a general mode of response for the sites whose cases are simpler than others. Angkor, for example, submitted its first SOC in 1993 and the response of the Committee is lengthy and full of analysis, creating an actual dialogue in preservation. On the other hand, the reaction to the 1993 SOC for the Hagia Sophia is only a paragraph as well. Considering the plethora of problems detailed in the previous UNESCO reports and the new political issues in Algeria, the discussion could have been far longer. However, considering it in the context of the Civil War and the political machinations that have taken ahold of World Heritage, this dialogue takes on a different image. Meskell's exploration of the politics surrounding SOC documents describes other political issues as decision makers. For example, in Panama, a preference for development over preservation managed to draw the support of the BRICS states because of a similar viewpoint. ${ }^{164}$

The issues raised in the SOC reports of this period do not include the ones caused by the severe unrest within the country. Yet, preservation issues that required specific and intense work were now further challenged by the toxic environment in Algeria. As described in Ordinance 67-281, preservation requires cooperation between the owners of the property and the government, a possibility essentially erased by the political climate. Even if preservation were a priority for the government, collaboration with the residents of the Casbah, a site that by all accounts during the Civil War was not particularly friendly. 165 The lack of cooperation also meant that the district could not be used as a symbol of identity by the government. Essentially, both the practical and theoretical necessities for preservation were missing for the Casbah in the 1990s.

In 1993 the only threats considered in the SOC are the legal framework and management system/plan. ${ }^{166}$ Considering the turmoil in Algiers at the time of the report, the term threat is almost laughable. At the WHC meeting that year the Committee was " informed that legislative measures and urban enhancement

\footnotetext{
${ }^{164}$ Lynn Meskell, “States of Conservation: Protection, Politics, and Pacting within UNESCO's World Heritage Committee," Anthropological Quarterly 87, no. 1 (Winter 2014), 232-234.

${ }^{165}$ Martinez, The Algerian Civil War 1990-1998, 98; 108

166 "State of Conservation: Kasbah of Algiers," 1993, http://whc.unesco.org/en/soc/1779.
} 
were already underway or in preparation for the safeguard and rehabilitation of the Kasbah of Algiers."167 The reality in Algeria was not a climate conducive to preservation. The State of Emergency initiated in February of 1992 was extended on February 7, 1993. ${ }^{168}$ Later that year the GIA (Groupe Islamique Armée) demanded that all foreigners leave the country, an action that, if taken seriously, would inhibit monitoring groups like ICOMOS from safely surveying the Casbah.

The next three SOC reports add in a third threat to the preservation of the Casbah to create a list of threats including legal framework, management system/plan, and human resources. ${ }^{169}$ The dialogue from this period can essentially be reduced to the Algerian delegation expressing their continued desire and efforts to preserve the Casbah and the WHC responding with appreciation. Over this time period, monetary assistance was requested on three separate occasions to aid in the preservation work. First, in 1993, 10,000 USD was given to aid in the creation of an overarching plan to safeguard the Casbah. Building on this, in 199518,900 USD was allocated for training architects to implement this plan. Another 8,700 USD was given in 1997 to train three architects in specific preservation techniques for the Casbah. ${ }^{170}$ This specific plan does not appear to be available anywhere for analysis. Rather, the lack of action evident from the 2001 SOC stands as evidence that these preparatory investments did not bear fruit.

The lack of action during this period combined with the tumultuous ground condition suggests that a move to the List of World Heritage in Danger may have drawn attention to the issues at hand. Yet, the increasing politicization of World Heritage in general sheds light on its exclusion from the List in Danger. After being inscribed on the List of World Heritage in Danger, the WHC would take a more active role in the preservation of the site. Instead of leaving the stewardship solely to the State Party, the WHC acts “"in consultation' but not in collaboration with the State-Party to "develop and adopt ... a

\footnotetext{
${ }^{167}$ Ibid.

${ }^{168}$ Martinez, The Algerian Civil War 1990-1998, xviii.

169 "State of Conservation: Kasbah of Algiers," 1994, http://whc.unesco.org/en/soc/1822.

170 "Kasbah of Algiers: Assistance," UNESCO, http://whc.unesco.org/en/list/565/assistance/.
} 
programme for corrective measures, and subsequently to monitor the situation of the site." ${ }^{171}$ In addition to added attention from the WHC, an inscription on the List of World Heritage in Danger also provides publicity that might inspire people internationally. ${ }^{172}$ Of course, this attention can be read in different ways. In the case of Algeria, increased worldwide attention may have proved detrimental to the government that had taken power in a coup. The continued denial of the government to either discuss the Civil War period or name it as such suggests a continued embarassment over the period. ${ }^{173}$ Considering that the government is the intermediary between UNESCO and the site itself, the meager SOC reports of the period and the unwillingness to list the Casbah as a site in danger suggests political motivations aimed to keep away unwanted attention and criticism. The recent example of the Russian delegate arguing against putting the Syrian sites on the List in Danger when even the Syrian delegate recognized the need is more extreme that what may have happened with the Casbah. ${ }^{174}$ Still, it is important to realize the political implications underlying a seemingly simple shift in designation. It is also possible that exterior monitoring was considered to be too dangerous over this period and that the claims of progress given by the Algerian representatives were taken at face value.

A new president, Liamine Zéroual came to power in 1994, though not through an election. Despite this non-democratic beginning, Zéroual would sincerely help steer Algeria back into stability. In November 1994, international mediation began in Rome facilitated by the Sant'Egidio religious community. This international interest in peace was soon matched by antagonistic forces that extended the terror beyond the Algerian border. First, in December 1994, an AirFrance flight was taken hostage in Algeria. The next year saw a series of bombings in Paris by the GIA. Though the Sant'Egidio Platform was signed in early 1995, the HCE immediately rejected it. Elections were planned for November of that year and, though a boycott was called by opposing powers, Liamine Zéroual was elected president for a

\footnotetext{
${ }^{171}$ Di Giovine, The Heritage-Scape, 320.

${ }^{172}$ Ibid, 324.

${ }^{173}$ Le Sueur, Between Terror and Democracy, 196.

${ }^{174}$ Meskell, "States of Conservation," 222.
} 
five-year term. A new constitution was ratified at the end of 1996 though questions have been raised about the unobserved election. ${ }^{175}$ Though terror persisted, through the late '90s, a law passed in 1998 returns to an interest in preservation.

Law 98-04 is more comprehensive than ordinance 67-281 as it both identifies sites and outlines protection plans for such sites. It does not even reference ordinance 67-281 in its list of preceding and relevant legislation, suggesting that it stands as its replacement. The structure of each is similar, offering separate sections for artifacts and built heritage. Sections are also present that expand on portions of the earlier ordinance such as expropriation. ${ }^{176}$ The most important addition, especially in relation to the Casbah, is the introduction of Safeguarded Sectors, a method to better preserve sites.

The critical point of this section is to move beyond recognizing sites as important (like ordinance 67-281) and work towards active preservation of these sites. In addition to governmental recognition, each protected sector must be accompanied by a permanent safeguarding and enhancement plan (Plan permenant de sauvegarde et de mise en valeur, or PPSMVSS). ${ }^{177}$ The expansion of the legal framework pertaining to heritage within this document makes it a critical piece in the Casbah's story. In the historical context of a stabilizing government guided by Zéroual, a law focusing on historic preservation reads as a sign of improved conditions and a potential desire to use historical sites to bolster legitimacy. In September, Zéroual announced that he would leave office before his first term ended, meaning that an election would take place in the next year.

Despite suspicions of an unfair election and calls to boycott it from the other candidates in the race, Abdelaziz Bouteflika was elected president on April 15, 1999. He is currently in the middle of his fourth term in office, two more than legally possible when he was initially elected. His background recalls the nation building of Ben Bella, Boumediene, Benjedid and mirrors the logic behind the recruitment of

\footnotetext{
${ }^{175}$ Ciment, Algeria: The Fundamentalist Challenge, 193.

${ }^{176}$ Section III, Ordinance 67-281, Journal Officiel January 23, 1968, 53; Chapter IV, Law 98-04, Journal Officiel, June 17, 1998, 8.

${ }^{177}$ Article 43, Law 98-04, Journal Officiel, 8.
} 
Boudiaf. Bouteflika's roots go back to the beginning of the FLN and the War of Independence that gave it political legitimacy. Though he certainly benefitted from Zéroual's moves towards reinstating democracy, Bouteflika's own laws truly helped bring the country back together after nearly a decade of turmoil. In what Le Sueur refers to as an attempt "to remove the cultural and political debris of history itself," two referendums on amnesty have been passed during the Bouteflika presidency. ${ }^{178}$ The 1999 and 2005 laws essentially sweep the issues of the past under the rug, hoping to move forward. A subtle effect of these laws is an erasure of wrongdoing on the part of the government and an erasure of the legitimate grievances against the FLN that launched the Civil War. ${ }^{179}$

In this context of a shifting relationship to history, the SOC reports continue as if the past ten years had never happened. With a return to stability, one might expect preservation of the Casbah to finally move forward. A four year period of silence in SOCs was broken in 2001with a more extensive response than previously seen. The more substantial response seems to come from a more in-depth report, reflecting the potential for better work with the renewed political stability. They reference a 1980 report that reported 200 collapsed buildings and 500 evacuated ones. ${ }^{180}$ It is as if the 1990 s never happened, glossing over the period of nearly ten years under UNESCO in which no preservation progress was made. The effects of time are noted, suggesting that recent deterioration "has provoked a state of imminent danger for the built and social fabric." 181 This report also clarifies that much of the preservation work that was supposedly done in the 1990s with monetary assistance from UNESCO was either not done or not done satisfactorily. A September 2001 mission, commissioned by the Algerian government is revealed here with the specific goal of preparing a preservation plan and helping clarify the need for training. ${ }^{182}$ Both the plan and the training are mentioned in previous SOC reports and appeals for monetary aid with

\footnotetext{
${ }^{178}$ Le Sueur, Between Terror and Democracy, 195.

${ }^{179}$ Ibid, 202.

180 "State of Conservation: Kasbah of Algiers," 2001, http://whc.unesco.org/en/soc/2549.

181 Ibid.

182 Ibid.
} 
the expectation that some progress had been made. Essentially, the 2001 report should be understood as the first true documentation of the Casbah as a World Heritage Site because it elucidates the ineffectiveness of the previous four.

The WHC meeting in early July, 2003 produced a lengthy response to the submitted SOC. Again, it pinpointed issues that had laid dormant for the entirety of the 1990s, and took on a harsher tone than previously seen. An extensive mission in the fall of 2002 allowed for this criticism to rise to the surface. Despite steady documentation since Independence, the study suggested that there was a lack of "appropriate documentation and monitoring of the monument." ${ }^{183}$ Highlighting a serious flaw in the UNESCO system, a massive project backed by Italy that included conservation training aimed at future action within the Casbah that was not directly reported to UNESCO was unearthed by this mission. ${ }^{184}$ In the Lower Casbah work is observed "that contravenes the conservation principles underlying the Convention," according to the ICOMOS delegate. ${ }^{185}$ Critically, the report goes on to describe the Casbah "unambiguously as a site in danger," and suggests that its severe issues have not "been attended to for a number of years." 186 Understanding the historical context of the previous eleven years as a World Heritage site, this final observation is not surprising. The tone of astonishment that accompanies it points to the ineffective nature of UNESCO, frozen by international politics and little potential punishment. Though William Logan details the nationalistic tendencies of the World Heritage program, he is largely defensive of UNESCO. ${ }^{187}$ This view does not hold UNESCO responsible at all, only highlighting its ineffective management of these cultural properties. Avoiding any potential blame by putting all of the expectations onto the State Party, it denies any power it might have taken. Logan shifts attention to the States Parties as the source of nationalism rather than the World Heritage Convention itself. Nationalism,

\footnotetext{
183 "State of Conservation: Kasbah of Algiers," 2003, http://whc.unesco.org/en/soc/2727.

184 Ibid.

185 Ibid.

186 Ibid.

${ }^{187}$ William Logan, "States, Governance and the Politics of Culture: World Heritage in Asia," in Routledge Handbook of Heritage in Asia, ed. Patrick Daly and Tim Winter (New York: Routledge, 2012).
} 
however, is built into the document, suggesting that some blame must rest on UNESCO but also that it has the power to combat these misuses of the idealistic convention. The politics that interfered with the World Heritage initiative during the Civil War, causing stagnation, deterioration, and danger to continue unabated, created this situation. As a complicit entity in the disregard for the site, these findings should not be alarming. The report avoids blaming the Algerian government outright by recognizing monetary restrictions. A policy previously suggested in the 1973 UNESCO study, suggesting that government aid be given to owners who wanted to rehabilitate their property, had evidently been enacted. However, the requirement that the owner pay $50 \%$ of the cost (also a stipulation present in the 1973 study) proved too restrictive, resulting in only fifteen permits taking advantage of the program. ${ }^{188}$ The report concludes with the suggestion that the PPSMVSS should be finished and implemented as quickly as possible. To follow up, an SOC was requested for the following year. In October 2003, executive decree 03-324 aimed to help put Article 45 of law 98-04 into action. ${ }^{189}$ As discussed before, this specific portion of law 98-04 requires a PPSMVSS, or Permanent Protection and Enhancement Plan for each Protected Sector. This additional legislation elaborates on what such a plan should entail and how it should be set up and enacted. The increasing amount of legal framework surrounding heritage in Algeria points to the stability under Bouteflika as well as a serious desire to act to preserve sites in the wake of the severe tone UNESCO took.Yet, the conditions of the Casbah were still far from ideal.

The 2004 SOC report presents a very different tone from the previous ones. First, they gratefully recognize the executive decree that described PPSMVSS, but the tone swiftly shifts to business. Rather than diplomatically and passively receiving the information on the site, the WHC took initiative. As discussed previously, a more active role is usually not taken by the WHC unless a site is on the List of World Heritage in Danger. This increased interest in the site as well as the astonished findings by the Committee and ICOMOS in 2001 and 2003 suggest that inscription on the List in Danger would have

\footnotetext{
188 "State of Conservation: Kasbah of Algiers," 2003, http://whc.unesco.org/en/soc/2727.

${ }^{189}$ Article 1, Executive decree 03-324, Journal Officiel, 15.
} 
helped keep the Casbah in the mind of the Algerian government and the WHC. The plan outlined in 2004 was based on a pair of missions to survey the site in October 2003 and early March $2004 .{ }^{190}$ While most UNESCO missions prior to this one were initiated by the Algerian government, these were organized by the WHC, though it is quick to highlight that this was done "in close cooperation with the State Party."191 The negative tone is replaced with the detailing of a plan, specifically surrounding technical education. It goes so far as to include the potential options for how they would obtain offices within the Casbah, evidently deciding between renting a building or buying a house. ${ }^{192}$ Optimism coming from the progress towards a solid plan can be read in this and echoing a desire for progress, an SOC report was requested for the next year.

In May 2005, the Casbah was finally named a Protected Sector. Since SOC reports are given to UNESCO in February, this advancement was only suggested in the report. The reason for the delay between the implementation of Protected Sectors in 1998 and this declaration is unknown. However, this was the very first decree of a Protected Sector, swiftly followed by two more in June 2005. Under law 98-04, a PPSMVSS would have to be formulated. The plan would follow three phases as outlined in the 2003 decree: diagnostics and drafting of urgent measures, historical and typological analysis and drafting of the final PPSMVSS, final writing of the official PPSMVSS. ${ }^{193}$ The first two phases are meant to be done at the same time. Considering the wealth of information generated on the Casbah for the past thirty years, it is strange to see research as the beginning point again. It creates the illusion that research is the beginning and end of all work done on the Casbah, especially since this documentary evidence is easier to come by than any concrete work. To that point, there is a single "technical sheet" available on the Casbah d'Alger website that supposedly details both the urgent works in progress and completed. ${ }^{194} \mathrm{~A}$ brief

\footnotetext{
190 "State of Conservation: Kasbah of Algiers," 2004, http://whc.unesco.org/en/soc/1435.

191 Ibid.

192 Ibid.

${ }^{193}$ Article 15, Executive Decree 03-324, Journal Officiel, October 8, 2003, 17; http://www.casbahdalger.dz/plan.html

194 “Casbah d'Alger,” http://www.casbahdalger.dz/001.pdf
} 
history of the site that reveals no new information is followed by a series of before and after pictures that does not do much beyond prove that minor work has been completed. The images feature interventions done in contrasting red material to call attention to their unnatural and temporary nature. (Fig. 16) In the SOC report, the WHC found the continuing progress of training and development of the PPSMVSS satisfactory and requested continuation of the work and an SOC report in 2007.

By 2007, the PPSMVSS was in progress with phases two and three "well under way." 195 Yet, the WHC expressed dismay at the short SOC report that was submitted and suggested that could not adequately assess the status of the site. ${ }^{196}$ With the length, certain threads were broken such as the work on the technical education center, whose absence in the report is noted. ${ }^{197}$ Still, there was a strong enough demonstration of on-going work to wait until 2009 to see another SOC report. At this point, with clear work being documented and implemented, the dialogue grows less urgent and involved while maintaining a level of attention that was present in the 1990s.

The SOC report of 2009 responded to the criticism of the last report and included information on the new "Documentation and Information Centre" now with the permanent location of "Dar Aziza Palace."198 The government structure surrounding the site is elucidated as well, explaining that "monitoring of the implementation of this Plan [the PPSMVSS] is currently ensured by a coordination body comprising representatives of all the decentralized structures of the State concerned with the management of the property as well as the Wali of Algiers, or his representative." 199 The one new element introduced in the report is the construction of the Algiers metro. A site was planned for the lower Casbah with necessary infrastructure required below the protected district. The ground below the built work was of particular interest due to the potential archaeological value of the site. ${ }^{200}$ With the progress on the Casbah appearing

\footnotetext{
195 "State of Conservation: Kasbah of Algiers," 2007, http://whc.unesco.org/en/soc/1012.

${ }^{196}$ Ibid.

${ }^{197}$ Ibid.

198 "State of Conservation: Kasbah of Algiers," 2009, http://whc.unesco.org/en/soc/661.

${ }^{199}$ Ibid.

${ }^{200}$ Ibid.
} 
satisfactory both in terms of actual work and monitoring structures, another two years passed before the next SOC report was due.

The descent relationship between the Algerian authorities and the WHC continued as shown in the response to the 2011 SOC report. Small issues remained such as a failure to deliver additional information on potential urban development plans that would possibly affect the Lower Casbah. It highlights the status of the PPSMVSS and its various phases, first mentioning that the emergency work of phase one was almost complete. Important numbers are included that offer a stronger understanding of the state of the Casbah in 2011. It counts 394 structures “as 'highly degraded.' Nineteen technical offices and more than 150 companies are mobilised. Studies have been conducted for $92 \%$ of the buildings, work on $80 \%$ of them is underway, and the work is completed for $66 \%$ of them. ${ }^{201}$ However, it is important to note that this work was only provisional, not a permanent solution. The significant amount of work does prove that changes have been made in the district, even if it took about twenty years to do so. Phase two is remarked as being complete and a wealth of information. Phase three, the final draft, was finished "and awaiting adoption by the Popular Assembly of the Wilaya of Algiers. ${ }^{, 202}$ Mitigation of the metro project is outlined, with the station avoiding potential archaeological data and suggesting that information about the site be presented within said station. ${ }^{203}$ The official final draft of the PPSMVSS was adopted on March 21, 2012 by executive decree and published in the Journal Officiel a week later. ${ }^{204}$

The 2013 SOC report and response continues the trend of satisfactory progress and a strong dialogue between parties involved. Mitigations surrounding the metro are reiterated and archaeological data is shared. ${ }^{205}$ The urban planning that was mentioned in previous SOC reports comes to light again here. "A new memorial at the Place des Martyrs" had been a part of the plan but was discarded due to the

\footnotetext{
201 "State of Conservation: Kasbah of Algiers," 2011, http://whc.unesco.org/en/soc/337.

${ }^{202}$ Ibid.

${ }^{203}$ Ibid.

${ }^{204}$ Executive decree 12-133, Journal Officiel March 28, 2012, $12-13$.

${ }^{205}$ Archaeological findings include "a basilica with polychrome mosaics and a cemetery," according to the SOC report.
} 
conflict it would cause in the protected public square. ${ }^{206}$ As far as actual preservation work in the Casbah, the report mentions that the provisionary emergency works were being followed by new "protection and enhancement activities. ${ }^{207}$ An extremely encouraging advancement in the relationship of the Algerian government to the owners of the Casbah buildings is also critical here. The government was solidifying its understanding of ownership and ameliorating the collaboration with them. Still, the report gives the sense that there is still significant work to be done, recalling that 266 owners called for rehabilitation and another 120 hoped that the state would buy their property. ${ }^{208}$ When the Casbah is discussed as a singular unit, it is difficult sometimes to understand the intricacy of the site and the plethora of buildings that it includes.

The final SOC report at this point is from 2015. It is very similar to the previous report, with further updates on the ongoing preservation work and urban development. In the never-ending maze of bureaucracy, the adoption of the PPSMVSS necessitated the development of an "action plan" which required multiple parties. ${ }^{209}$ Representatives from the central government, the Wilaya, and a local group were all involved in its drafting in 2014. The main concerns include coordination and the general implementation of the plan and the situation will be assessed by the WHC again in 2017. Even if the first ten years of the Casbah's World Heritage status are ignored, another fifteen years have passed with minimal work done. Though recent SOC reports contain an optimistic tone and a narrative of forward progress, the true role of the PPSMVSS will come in the future when its implementation and effects can be properly assessed.

\footnotetext{
206 "State of Conservation: Kasbah of Algiers," 2013, http://whc.unesco.org/en/soc/1891.

${ }^{207}$ Ibid.

${ }^{208}$ Ibid.

209 "State of Conservation: Kasbah of Algiers,” 2015, http://whc.unesco.org/en/soc/3265.
} 


\section{Conclusion}

In 2009, Kahina Amal Djiar looked into the living conditions for the people of the Casbah. She manages to offer an image of the overcrowding of the Casbah that goes beyond the slew of numbers packed in UNESCO studies. Since they can be outfitted with necessary modern amenities, "bedrooms are considered to be small individual studio units," she explains, that are "occupied by entire nuclear families, or even in some cases by larger extended-type families." ${ }^{210}$ This depressing image degrades further as she relates the shift in meaning of the various house spaces. Areas that used to be significant in their original Ottoman setting like the entrance hall or courtyard shifted into essentially useless spaces. Most activities moved to the already cramped bedrooms. ${ }^{211}$ This critical overcrowding of the district is underlined by six specific issues Djiar found in a survey of the Casbah residents. Only one of the issues pertains to the actual degradation of the buildings. More important is the density of function as well as people. ${ }^{212}$ As seven years have passed since the publication of this article, it is possible that conditions have improved. Yet, February 23, 2016 marked the 26th National Casbah day in Algeria, which was distinguished this year by the announcement that a new preservation plan would target 200 traditional houses. ${ }^{213}$ The urgent tone suggests that the state of the Casbah has not, unfortunately, improved. Despite the positive tone of the past few SOC reports, the reality of the Casbah is still less than ideal.

The way the author treats the Casbah within the article, though, indicates just how important the site still is today. Described as a "Lieu de mémoire et témoin de notre histoire," its history is outlined solely in relation to its role in the War for Independence. She goes so far as to say that "on n'a pas le droit d'oublier une ville qui a payé un lourd tribut durant la Guerre de Libération nationale."214 This persistent state of disrepair sets the Casbah apart from other World Heritage Sites.

\footnotetext{
${ }^{210}$ Djiar,"Locating Architecture, Post-Colonialism and Culture", 177-178.

${ }^{211}$ Ibid, 177.

212 Ibid, 175.

${ }^{213}$ Nora Chergui, "Le Président de la Fondation Casbah: $<<\mathrm{Il}$ faut sauver la Médine $>>$," El Moudjahid, February 22 , 2016, sec. Nation.

${ }^{214}$ Ibid, Translation: "we don't have the right to forget a city that paid a heavy price during the National Liberation War."
} 
For journalists worldwide, the deterioration of the Casbah has been a tantalizing subject. As Jarzombek points out, it is human nature to be drawn to material evidence of time passing us by. ${ }^{215}$ Yet, this depressing reality of time is not the typical image of a World Heritage site. It positions the Casbah as the antithesis of the UNESCO brand. Jarzombek is also quick to call attention to the pristine photos used to promote its programs and sites where "there is never any snow, rain, or sleet, and above all, no signs of poverty." ${ }^{216}$ This trend extends as well to signs of severe deterioration. The photo gallery that accompanies the listing of the Casbah on the UNESCO site avoids showing images of the more extreme cases, but still cannot entirely avoid the pervasive signs of decline. These news articles move beyond the positive SOC reports and images to the real conditions, just as Djiar has done. In the process, however, the romanticization of ruins can be detected. The New York Times ran a piece in 2006, the Smithsonian in 2007, and Reuters in 2008. More recently, a January 2016 article continues the trend and sobers any enthusiasm influenced by progress with the PPSMVSS.

The recurrence of these stories and the interest in ruinous state of the Casbah begs the question: has deterioration become the image of the Casbah? Only one of the three articles is positive. Titled "A ray of hope for Algeria's crumbling Casbah?" the 2008 story still cannot resist the image of the medina in ruin. ${ }^{217}$ Even the referenced "ray of hope" is not terribly bright. It refers to three million dinars being presented as a part of a plan to restore the district. The rest of the article is filled to the brim with colorful descriptions of disrepair, a "haunting Ottoman settlement," and a "fissure-ridden slum of mostly graying, rotting buildings." ${ }^{218}$ The image that accompanies the text shows the bombed out Ali La Pointe house with no understanding of context. The caption reads "a view of old Moorish houses in the old city of Casbah in Algiers," a clear misunderstanding of the district as a whole, not just the site of the photograph.

\footnotetext{
${ }^{215}$ Jarzombek, "The Metaphysics of Permanence - Curating Critical Impossibilities," 130.

${ }^{216}$ Ibid, 129.

${ }^{217}$ William Maclean, “A Ray of Hope for Algeria’s Crumbling Casbah?,” Reuters, August 31, 2008, http://www.reuters.com/article/us-algeria-casbah-idUSLB44107820080901.

${ }^{218}$ Ibid.
} 
${ }^{219}$ A similar interest in the power of ruins is clear in the New York Times article "The Crumbling of the Casbah."220 The three images that accompany this article provide a romantically decaying backdrop for the heartbreaking stories that make up the meat of the work. Each of the three articles from the late ' $00 \mathrm{~s}$ ultimately place blame on the government for their inaction. ${ }^{221}$ The latest article, “Algiers' tumbledown Casbah stirs loyalty among residents" reads as a check-up to assure that the state of deterioration hasn't changed. ${ }^{222}$ These articles describe the same cycle of reality and optimism that has been driving forward the preservation movement throughout this story. Continual recognition of the poor conditions is countered by the hope that maybe this time something will happen. What sets these stories apart is their use of people to foreground the consequences of once again failing to act.

The French colonial period set the indigenous residents of the Casbah against their French oppressors. The urban form became a site for the power dynamics of the time to play out, resulting in destruction of the Casbah and its relegation to the past. Residents of the medina were lumped together as a single entity expressed in their oriental image. No consequences would come from neglecting the Casbah or its people. Hope remained for the residents as they built a tight community. Independence moved Algeria forward, though ethnic lines of separation between the Casbah and the rest of the city were replaced with socioeconomic ones. A lack of money and expertise now stood in the way of preserving the Casbah. A deep love for the site, continued studies, and intermittent work brought hope for better conditions. Yet, the list of issues with the site only grew, and preservation is far more complex than just willing it into existence. The idea of preservation was far more enticing than the actual action. Described as lost time due to the danger of the site, the 1990s are a rehashing of the colonial period, with the

\footnotetext{
219 Ibid.

${ }^{220}$ Craig S. Smith, "The Crumbling of the Casbah,” New York Times, July 23, 2006, sec. Art \& Design, http://www.nytimes.com/2006/07/23/arts/design/23smit.html?pagewanted=1\& r=0.

${ }^{221}$ Joshua Hammer, "Save the Casbah,” Smithsonian Magazine, July 2007, http://www.smithsonianmag.com/making-a-difference/save-the-casbah-157542999/?no-ist.

${ }^{222}$ Zohra Bensemra, “Algiers' Tumbledown Casbah Stirs Loyalty among Residents,” Reuters, January 21, 2016, http://www.reuters.com/article/us-algeria-casbah-widerimage-idUSKCNOUZ1WK.
} 
residents of the Casbah set against the government. ${ }^{223}$ The present day dynamic includes government endorsed plans for the site that has remained socioeconomically isolated from the rest of the city. It seems that there is nothing for the residents to do but hope. If the pragmatic capitalist characterization of the government in these news articles is accepted, no true change will come about unless there is a clear benefit. Some residents and outsiders fight for preservation in non-governmental organizations like Fondation Casbah, Sauvons la Casbah, or Association DARNA 224 are grassroots organizations that aim to improve the Casbah in any way they can. Perhaps ending reliance on the government for action is the most effective way to break this cycle.

All the while, the mysterious air of the Casbah has been replaced by its destruction. All of the tropes are present when these journalists describe the Casbah as a "labyrinth," and "a gloomy world of shadows and dust, of braying donkeys and veiled women." ${ }^{225}$ It is reminiscent of the fascination that drew European tourists to the site in the colonial era. Now the target of that interest has shifted. While each author revels in writing about a site that they clearly find captivating, that awe is eclipsed by a enchantment with destruction and poverty. A true empathy for the plight of the residents is no match for the ravages of time. Their vocabulary is exercised as they work to describe the state of the site. It becomes an assemblage of "fissure-ridden houses reeking of sewage and uncollected garbage." 226 The images back up the words: the Casbah is crumbling and it has an audience.

As a site constantly portrayed on the international level as little more than a ruin or a slum, it is imperative that this classification does not become conflated with Algerian culture at large. It is easy to read too much into the Casbah and make it a representative of a whole culture. Even the New York Times falls victim, calling the isolation of the Casbah symbolic for "radical Islam's retreat from modernity."227

223 Craig S. Smith, "The Crumbling of the Casbah," 3.

224 "Association DARNA," http://darnadz.org/presentation/

${ }^{225}$ Maclean, “A Ray of Hope for Algeria’s Crumbling Casbah?,"; Hammer, "Save the Casbah,"

${ }^{226}$ Hammer, "Save the Casbah,"

${ }^{227}$ Smith, "The Crumbling of the Casbah," 1. 
Separating the image of the medina from the image of the state is especially difficult considering the sense that the government wanted part of its image to be its cultural heritage. Jarzombek explains the conflation further with examples like the Taj Mahal as a visual synecdoche for India. ${ }^{228}$ Yet, he is also a critic of the pristine image of heritage that "evacuates temporality from the architectural to produce an imaginary cultural calm in the swirling stew of reality." ${ }^{229}$ In this new context, the state of the Casbah is more authentic in its image, it does not clean up reality. This authenticity still has to exist within the constructed system of World Heritage, however, as the bridge between past and present. While this is usually seen as a positive construct, as an image of the Algerian state as well as its cultural past, the conflation of part and whole and collapse of time give two false images. First, the idea that the Casbah represents Algeria and that the poverty of the site is reflective of the state as a whole. This is similar to the outsider interest in slums. Second, it gives the false sense that these conditions were the conditions of the past during the Ottoman Empire. As poverty and deterioration are tied together in the Casbah, the juxtaposition with the European city below is heightened, making a visual argument that the French improved the city. An already misunderstood method of planning is overlaid with yet another erroneous image to fight against, relegating it further into the past. The Casbah is a beautifully complex space that deserves to be saved not only for the memory of its intricate urban planning and brilliant passive design but also for the people who live there. Hope and disappointment have become too familiar a cycle, however, suggesting that the government should not be relied on. The way forward to preserve the Casbah is difficult, but that is old news.

\footnotetext{
${ }^{228}$ Jarzombek, “The Metaphysics of Permanence - Curating Critical Impossibilities,”, 127.

${ }^{229}$ Ibid, 131.
} 


\section{Bibliography}

Algerian Documents

“Arrêté du 12 septembre 1973.” Journal Officiel de la République Algerienne. (Algiers, Algeria) November 13 1973. 1059.

“Arrêté du 24 novembre 1991.” Journal Officiel de la République Algerienne. (Algiers, Algeria) November 24 1991. 1926.

“Décret exécutif 03-324, October 5 2003.” Journal Officiel de la République Algerienne. (Algiers, Algeria) October 8 2003. 15.

“Décret exécutif 05-173, May 9 2005.” Journal Officiel de la République Algerienne. (Algiers, Algeria) May 11 2005. 4.

“Décret exécutif 12-133, March 21 2012.” Journal Officiel de la République Algerienne. (Algiers, Algeria) March 28 2012. 12.

“Loi 98-04, June 15 1998.” Journal Officiel de la République Algerienne. (Algiers, Algeria) June 17 1998. 3.

“Ordonnance 67-281, December 20 1967.” Journal Officiel de la République Algerienne. (Algiers, Algeria) January 23 1968. 50.

“Ordonnance 73-38, July 25 1973.” Journal Officiel de la République Algerienne. (Algiers, Algeria) August 28 1973. 805.

Republic of Algeria. "Convention Concerning the Protection of the World Cultrual and Natural Heritage Nomination Submitted by the Democratic and Popular Republic of Algeria: Dey's Palace." Republic of Algeria, April 1979. http://unesdoc.unesco.org/images/0003/000378/037826eb.pdf.

\section{UNESCO Documents}

Bouineau, Alain. "Citadelle d'Alger: Expertise des travaux de protection provisoire et des travaux de restauration proposés.” Paris: UNESCO, June 1985.

http://unesdoc.unesco.org/images/0006/000667/066735fo.pdf.

Casbah d'Alger. Plan Permanent de Sauvegarde et de Mise en Valeur du Secteur Sauvegardé de la Casbah d'Alger. UNESCO, 2009. http://www.casbahdalger.dz/plan.html.

"Convention Concerning the Protection of the World Cultural and Natural Heritage." UNESCO.

November 16 1972. http://whc.unesco.org/en/conventiontext/

Doulcier, J., K. Pawlowski, and L. Sato. "Révalorisation de la Casbah d'Alger.” Paris: UNESCO, July 1973. http://unesdoc.unesco.org/images/0000/000066/006627fb.pdf. 
Intergovernmental Committee for the Protection of the World Cultural and Natural Heritage. "Operational Guidelines for the Implementation of the World Heritage Convention.” UNESCO, July 2013. http://whc.unesco.org/archive/opguide13-en.pdf.

Kasbah of Algiers. UNESCO. Accessed November 18, 2014. http://whc.unesco.org/en/list/565.

“Kasbah of Algiers: Assistance.” UNESCO. http://whc.unesco.org/en/list/565/assistance/.

Lézine, Alexandre. "Algérie conservation et restauration des monuments historiques." Paris: UNESCO, July 1964. http://unesdoc.unesco.org/images/0013/001357/135791fo.pdf.

—. "Algérie conservation et restauration des monuments historiques." Paris: UNESCO, August 1966. UNESCO. unesdoc.unesco.com.

Ravéreau, André, and Sameh El Alaily. "Opération de sauvegarde et de restauration du bastion 23, Alger.” Paris: UNESCO, 1981. http://unesdoc.unesco.org/images/0004/000443/044391fo.pdf.

Saba, H. "Mesures légaslatives afférentes à la Casbah d'Alger." Paris: UNESCO, June 1980. http://unesdoc.unesco.org/images/0004/000406/040619fb.pdf.

"State of Conservation: Kasbah of Algiers," 1993. http://whc.unesco.org/en/soc/1779.

"State of Conservation: Kasbah of Algiers," 1994. http://whc.unesco.org/en/soc/1822.

"State of Conservation: Kasbah of Algiers," 1995. http://whc.unesco.org/en/soc/2037.

"State of Conservation: Kasbah of Algiers," 1996. http://whc.unesco.org/en/soc/2079.

"State of Conservation: Kasbah of Algiers," 2001. http://whc.unesco.org/en/soc/2549.

"State of Conservation: Kasbah of Algiers," 2003. http://whc.unesco.org/en/soc/2727.

"State of Conservation: Kasbah of Algiers," 2004. http://whc.unesco.org/en/soc/1435.

"State of Conservation: Kasbah of Algiers," 2005. http://whc.unesco.org/en/soc/1305.

"State of Conservation: Kasbah of Algiers," 2007. http://whc.unesco.org/en/soc/1012.

"State of Conservation: Kasbah of Algiers," 2009. http://whc.unesco.org/en/soc/661.

"State of Conservation: Kasbah of Algiers," 2011. http://whc.unesco.org/en/soc/337. 
"State of Conservation: Kasbah of Algiers," 2013. http://whc.unesco.org/en/soc/1891.

"State of Conservation: Kasbah of Algiers," 2015. http://whc.unesco.org/en/soc/3265.

Stefanaggi, M. "Palais des Beys et maisons de la Casbah." Paris: UNESCO, December 1977. http://unesdoc.unesco.org/images/0002/000248/024807fo.pdf.

Vauzelles Barbier, Dorothée, Jan Gontarczyk, Georges Filliat, Ogus J. Lengyel, and André de Ravignan. "Mission d'Assistance préparatoire Revalorisation de la Casbah d'Alger." Paris: UNESCO, 1978. http://unesdoc.unesco.org/images/0003/000321/032150fb.pdf.

“World Heritage Committee First Session.” UNESCO, June-July, 1977. http://whc.unesco.org/archive/1977/cc-77-conf001-9_en.pdf.

“World Heritage Committee Fifth Session.” UNESCO, October 1981. http://whc.unesco.org/archive/1981/cc-81-conf003-6 e.pdf.

“World Heritage Committee Fifteenth Session." UNESCO, December 1991. http://whc.unesco.org/archive/1991/sc-91-conf002-15e.pdf.

“World Heritage Committee Sixteenth Session.” UNESCO, December 1992. http://whc.unesco.org/archive/1992/whc-92-conf002-12e.pdf.

“World Heritage List No. 555.” ICOMOS, November 1991.

Other Sources Consulted

Ashcroft, Bill, Gareth Griffiths, and Helen Tiffin. The Empire Writes Back. Second. New York: Routledge, 2002.

Bensemra, Zohra. "Algiers' Tumbledown Casbah Stirs Loyalty among Residents." Reuters, January 21, 2016. http://www.reuters.com/article/us-algeria-casbah-widerimage-idUSKCNOUZ1WK.

Blas de Roblès, Jean-Marie, and Claude Sintes. Sites et Monuments Antiques de l'Algérie. Aix-en-Provence: Édisud, 2003.

Bouineau, Alain. "Citadelle d'Alger: Expertise des travaux de protection provisoire et des travaux de restauration proposés." Paris: UNESCO, June 1985. http://unesdoc.unesco.org/images/0006/000667/066735fo.pdf. 
Çelik, Zeynep. Urban Forms and Colonial Confrontations: Algiers under French Rule. Berkeley: University of California Press, 1997.

Çelik, Zeynep, Julia Clancy-Smith, and Frances Terpak, eds. Walls of Algiers: Narratives of the City through Text and Image. Seattle: The Getty Research Institute, in association with the University of Washington Press, 2009.

Chergui, Nora. "Le Président de la Fondation Casbah: $<<\mathrm{Il}$ faut sauver la Médina $>>$." El Moudjahid, February 22, 2016, sec. Nation.

Ciment, James. Algeria: The Fundamentalist Challenge. New York: Facts on File, Inc., 1997.

Cresti, Federico. "Algiers in the Ottoman Period: The City and Its Population." In The City in the Islamic World, edited by Salma K. Jayyusi, 1:407-43. Boston: Brill, 2008.

Delpont, Eric, Djamila Chakour, and Yannis Koïkas, eds. L'Algérie En Héritage, Art et Histoire. Arles: Institut du Monde Arabe/Actes Sud, 2003.

Di Giovine, Michael. The Heritage-Scape: UNESCO, World Heritage, and Tourism. Lanham, MD: Lexington Books, 2009.

Djiar, Kahina Amal. "Locating Architecture, Post-Colonialism and Culture: Contextualisation in Algiers." The Journal of Architecture 14, no. 2 (April 2009): 161-83.

—. "Symbolism and Memory in Architecture: Algerian Anti-Colonial Resistance and the Algiers Casbah.” Journal of North African Studies 14, no. 2 (June 2009): 185-202.

Ennahid, Said. “Access Regulation in Islamic Urbanism: The Case of Medieval Fès.” The Journal of North African Studies 7, no. 3 (Fall 2002): 119-34.

Fanon, Franz. A Dying Colonialism. Translated by Haakon Chevalier. New York: Grove Press, Inc., 1965.

Fikra 2014: Belkacem Babaci. Youtube Video, 2014. https://www.youtube.com/watch?v=TgrMQZN55oY.

Golvin, Lucien. Palais et Demeures d'Alger à La Période Ottomane. Aix-en-Provence: Edisud, 1988. 
Grabar, Henry S. "Reclaiming the City: Changing Urban Meaning in Algeria after 1962." Cultural Geographies 21 (409 389AD): 2014.

Hamadeh, Shirine. "Creating the Traditional City: A French Project." In Forms of Dominance: On the Architecture and Urbanism of the Colonial Enterprise, edited by Nezar AlSayyad. Brookfield, USA: Avebury, 1992.

Hammer, Joshua. "Save the Casbah.” Smithsonian Magazine, July 2007. http://www.smithsonianmag.com/making-a-difference/save-the-casbah-157542999/?no-ist.

Hill, Jonathan N.C. "Identity and Instability in Postcolonial Algeria." Journal of North African Studies 11, no. 1 (March 2006): 1-17.

Jarzombek, Mark. “The Metaphysics of Permanence - Curating Critical Impossibilities.” Log 21 (Winter 2011): 125-35.

Kepel, Gilles. Exils et Royaumes: Les Appartenances Au Monde Arabo-Musulman Aujourd'hui. Paris: Presses de la Fondation nationale des sciences politiques, 1994.

Koolhaas, Rem. “Cronocaos.” Log 21 (Winter 2011): 119-23.

Lesbet, Djaffar. La Casbah. Algiers: Office des Publications Universitaires Alger, 1985.

Le Sueur, James. Between Terror and Democracy: Algeria since 1989. New York: Zed Books, 2010.

Logan, William. "States, Governance and the Politics of Culture: World Heritage in Asia." In Routledge Handbook of Heritage in Asia, edited by Patrick Daly and Tim Winter. New York: Routledge, 2012.

Maclean, William. “A Ray of Hope for Algeria’s Crumbling Casbah?” Reuters, August 31, 2008. http://www.reuters.com/article/us-algeria-casbah-idUSLB44107820080901.

Martinez, Luis. The Algerian Civil War 1990-1998. Translated by Jonathan Derrick. London: Hurst \& Company, 2000.

Meskell, Lynn. "States of Conservation: Protection, Politics, and Pacting within UNESCO's World Heritage Committee." Anthropological Quarterly 87, no. 1 (Winter 2014): 217-43. 
Missoum, Sakina. Alger à L'époque Ottomane: La Médina et La Maison Traditionnelle. Aix-en-Provence: Edisud, 2003.

Naylor, Philip C. France and Algeria A History of Decolonization and Transformation. University Press of Florida, 2000.

O'Keefe, Patrick J., and Lyndel V. Prott, eds. Cultural Heritage Conventions and Other Instruments. UK: Institute of Art and Law, 2011.

Organization of African Unity. “Charte Culturelle de l'Afrique,” July 5, 1976.

Raymond, André. “The Spatial Organization of the City.” In The City in the Islamic World, edited by Salma K. Jayyusi, 1:47-70. Boston: Brill, 2008.

Ruedy, John. Modern Algeria: The Origins and Development of a Nation. Second. Indianapolis: Indiana University Press, 2005.

Said, Edward. Orientalism. New York: Penguin Books, 1995.

Smith, Craig S. "The Crumbling of the Casbah.” New York Times, July 23, 2006, sec. Art \& Design. http://www.nytimes.com/2006/07/23/arts/design/23smit.html?pagewanted=1\&_r=0. 


\section{Illustrations}

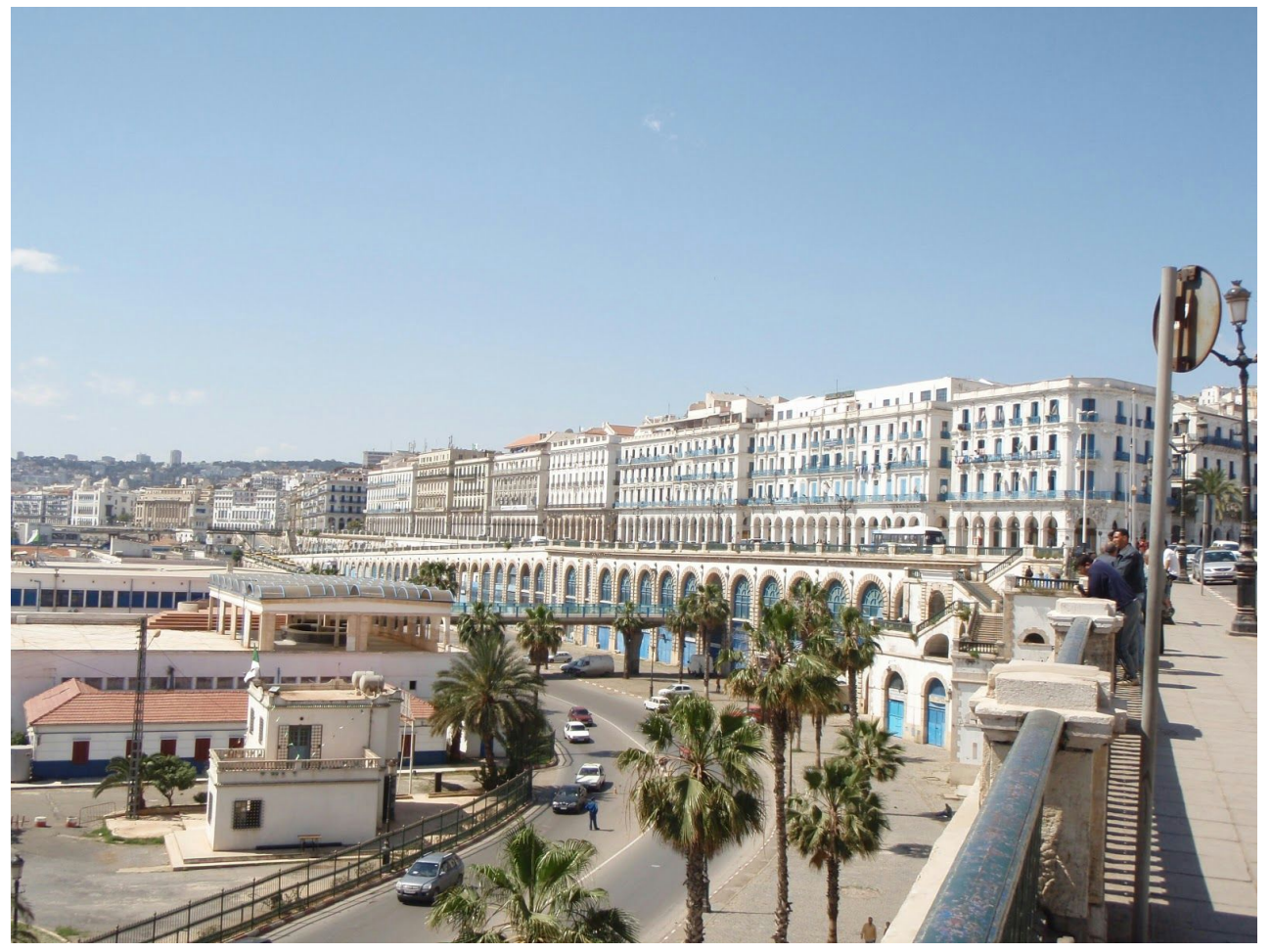

Fig. 1 - Sandervalya, Boulevard front de mer, April 18 2008,

https://commons.wikimedia.org/wiki/File:Alger-centre_front_de_mer.JPG

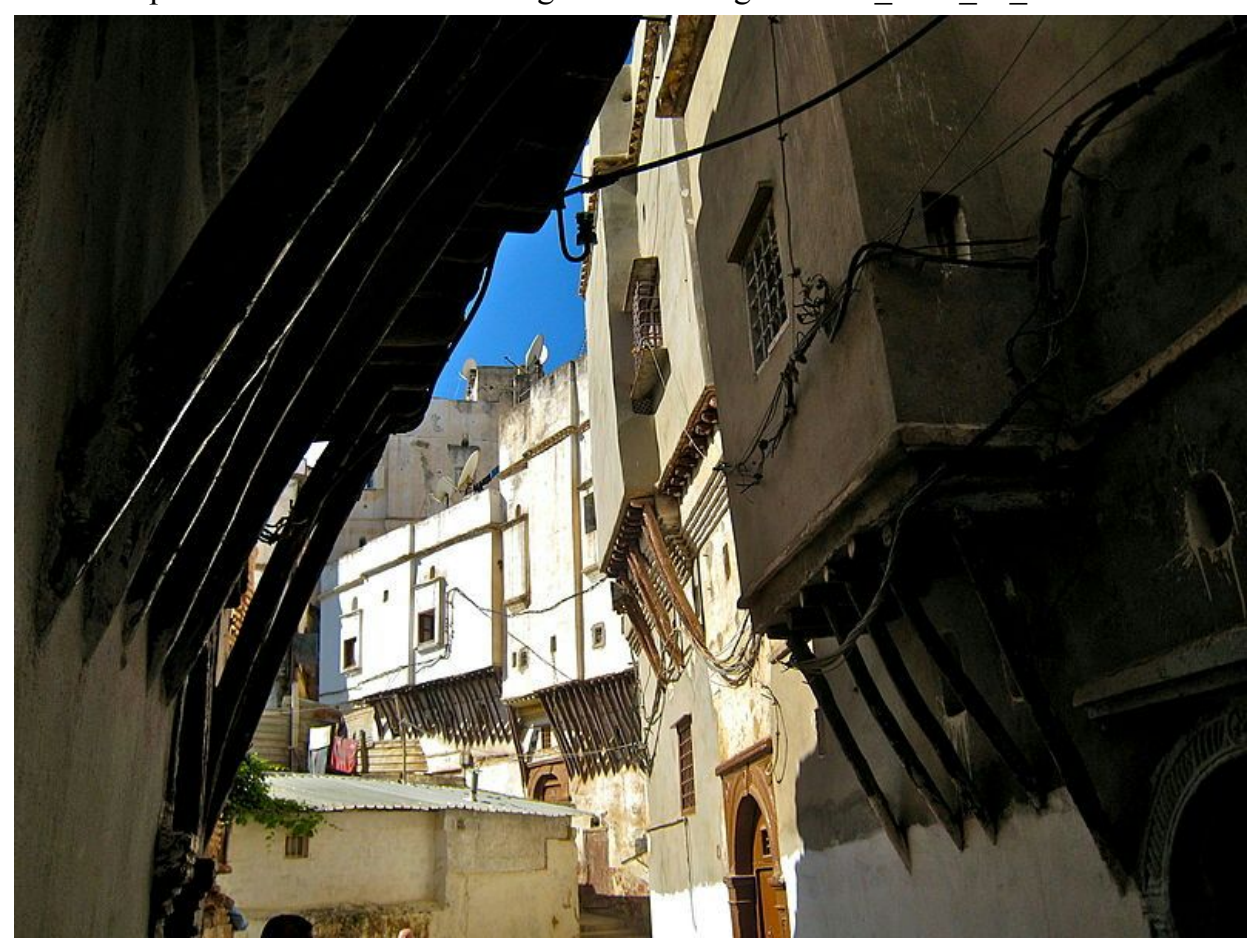

Fig. 2 - Jean-Marie Pirard, Etage en surplomb de la rue en haute Casbah, Oct. 20 2007, https://commons.wikimedia.org/wiki/File:Ruelle dans la haute_casbah_Alger.JPG. 


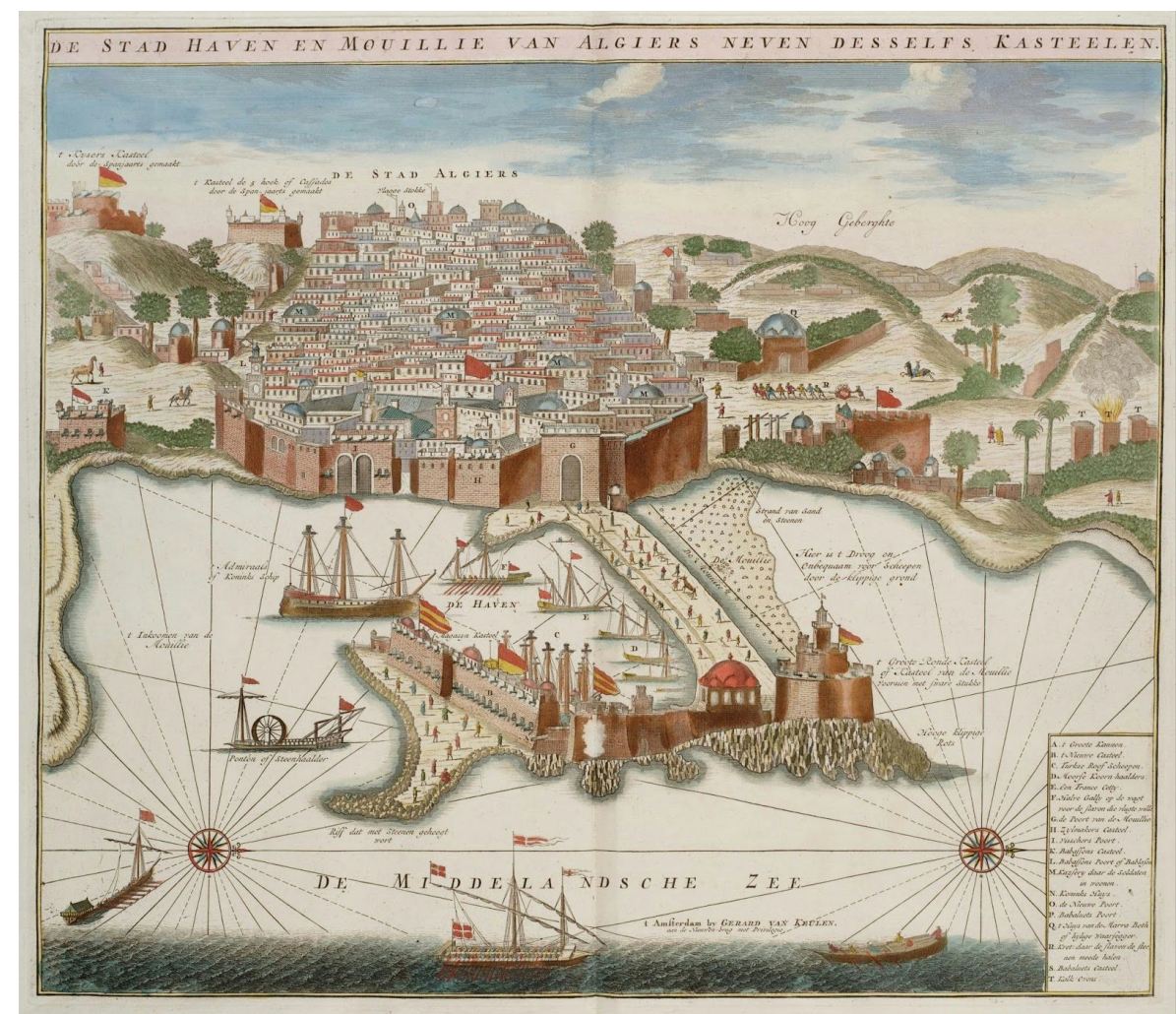

Fig. 3 - Gerard van Keulen, Algiers c. 1690,

https://en.wikipedia.org/wiki/Timeline of Algiers\#/media/File:La cite le port et le mole d Alger.jpg

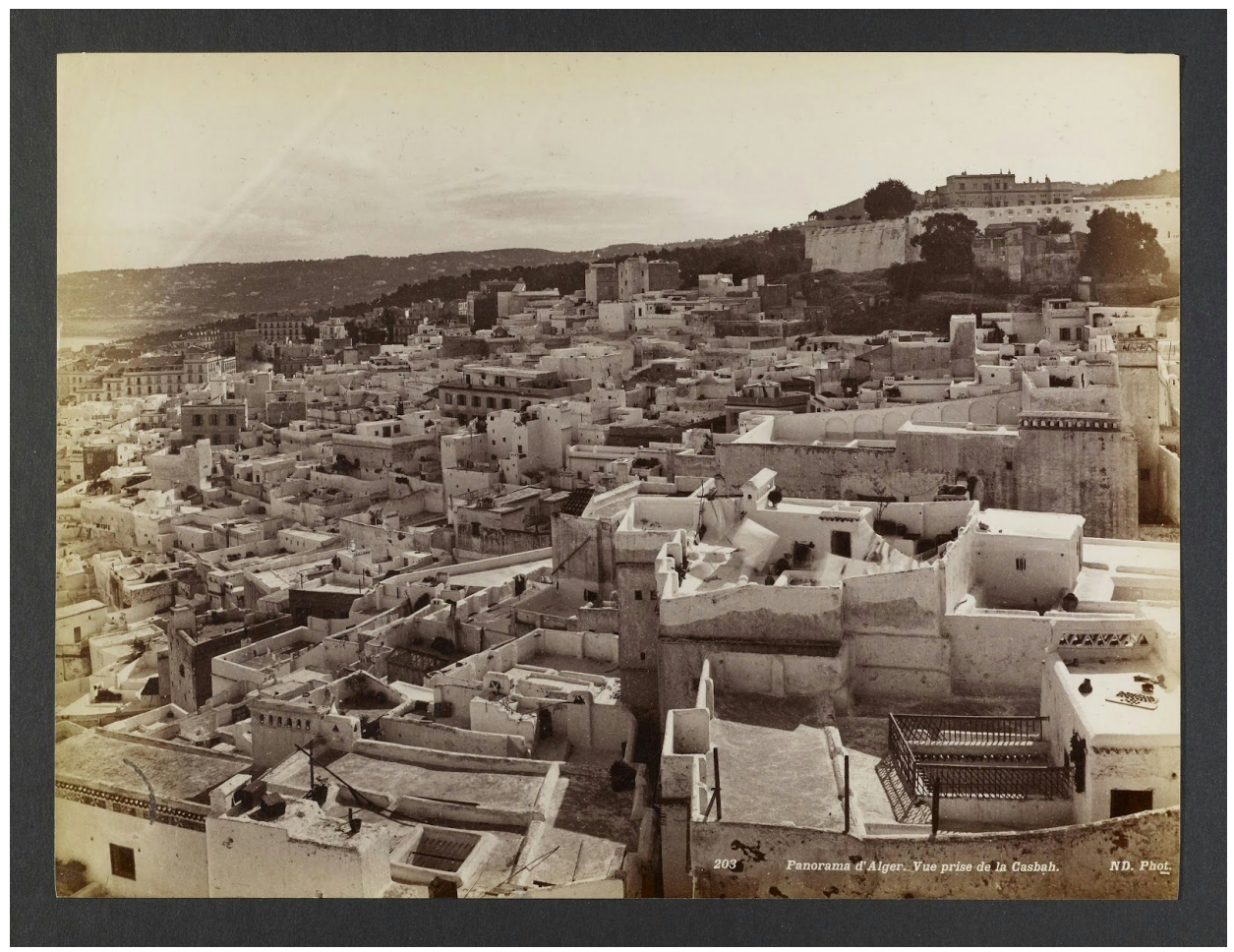

Fig. 4 - Neurdein frères, Panorama d'Alger. Vue prise de la Casbah, Getty Research Institute, http://hdl.handle.net/10020/2008r3 4020. 


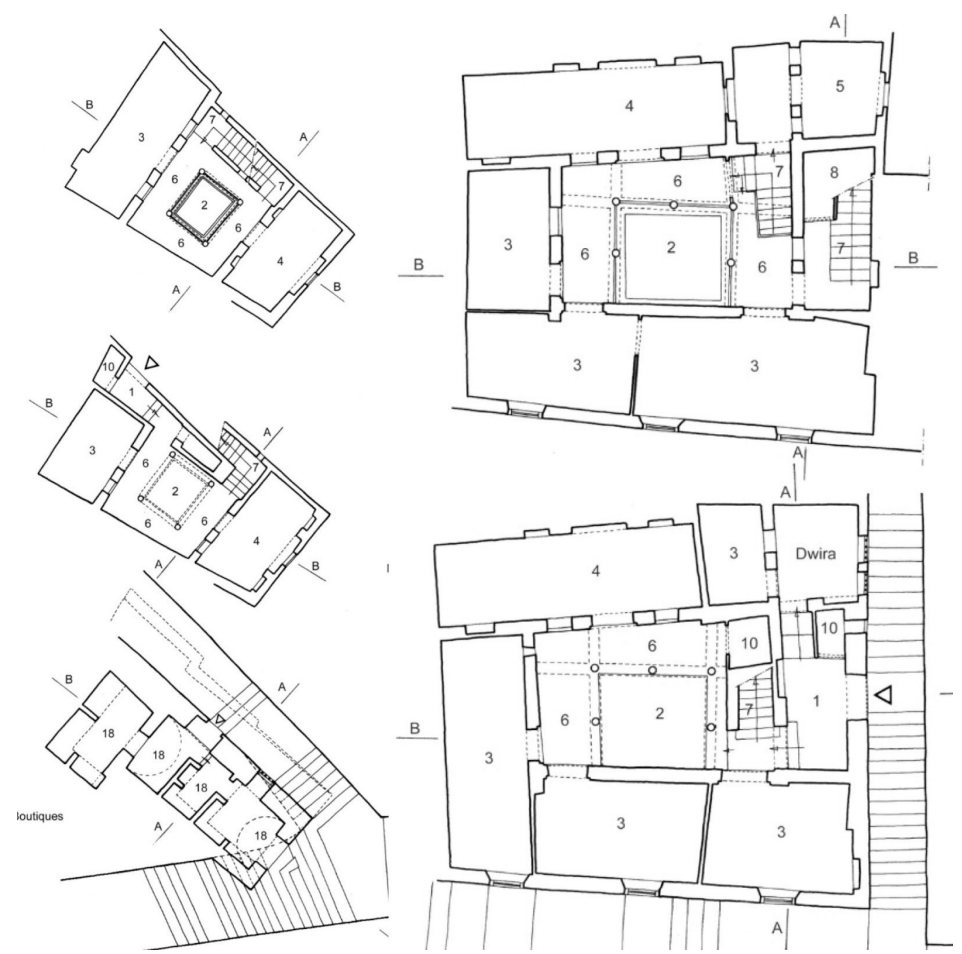

Fig. 5 - Sakina Missoum, Alger à L'époque Ottomane: La Médina et La Maison Traditionnelle (Aix-en-Provence: Edisud, 2003).

Left: Dar avec Chbak II.2 Raiah Rabah, 2; Right: Dar I.14 Impasse Sidi Driss Hamidouche, 2.
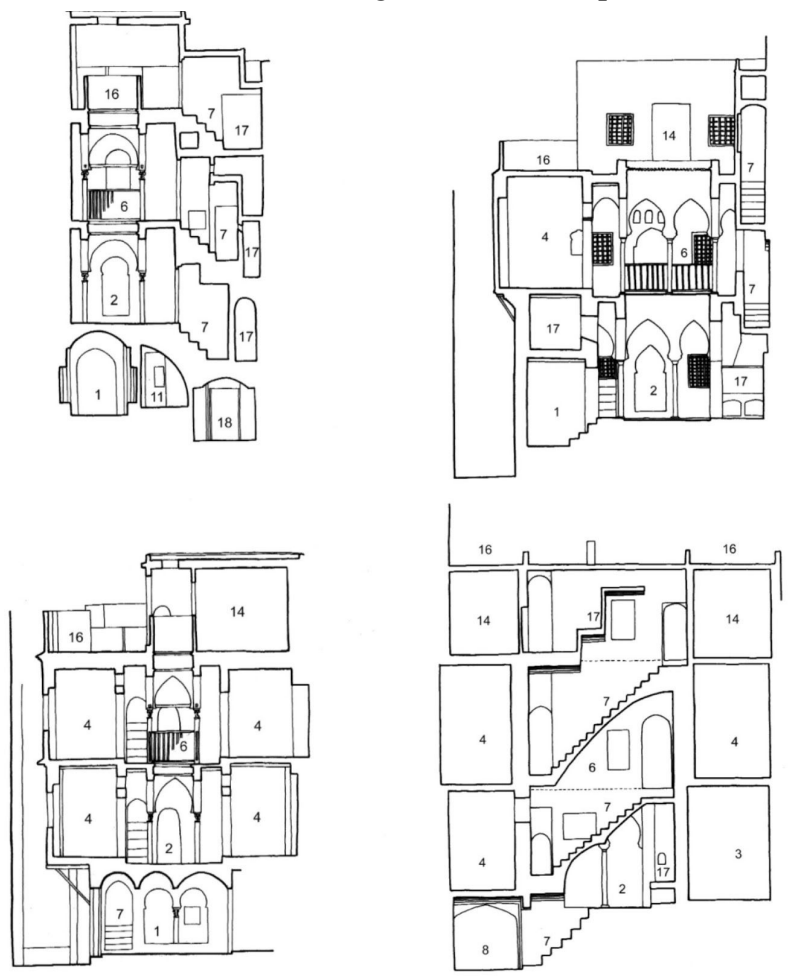

Fig. 6 - Sakina Missoum, Alger à L'époque Ottomane: La Médina et La Maison Traditionnelle (Aix-en-Provence: Edisud, 2003).

Left: Dwira II.5 Raiah Rabah, 6; Right: Dar II.3 Raiah Rabah, 4. 


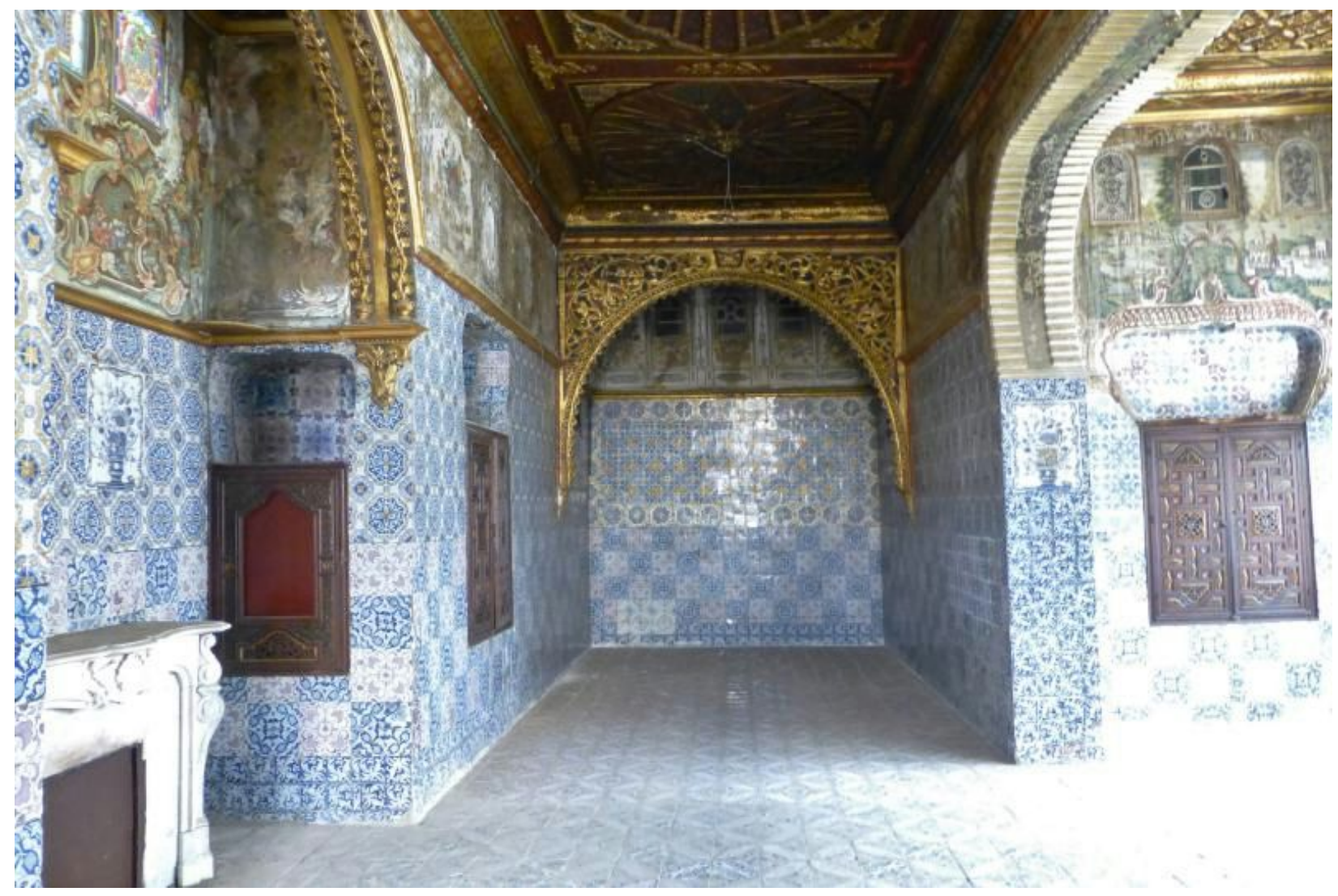

Fig. 7 - Yves Jalabert, Intérieur de Dar Hassan Pacha. Alger. May 9 2013, https://commons.wikimedia.org/wiki/File:Darhassanpacha_(2).jpg

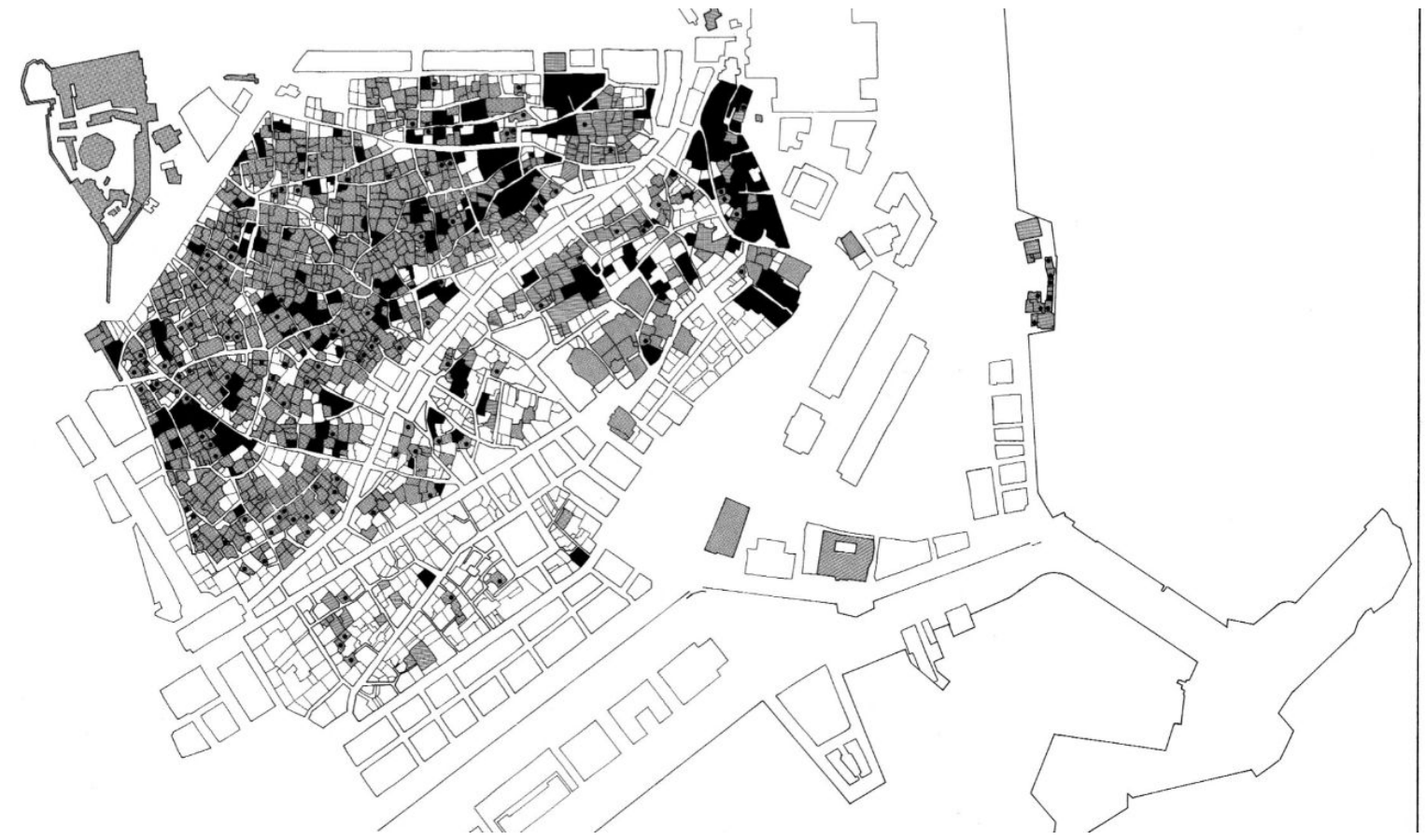

Fig. 8 - Sakina Missoum, “Algiers. Current state of the historic center," Alger à L'époque Ottomane: La Médina et La Maison Traditionnelle (Aix-en-Provence: Edisud, 2003). 


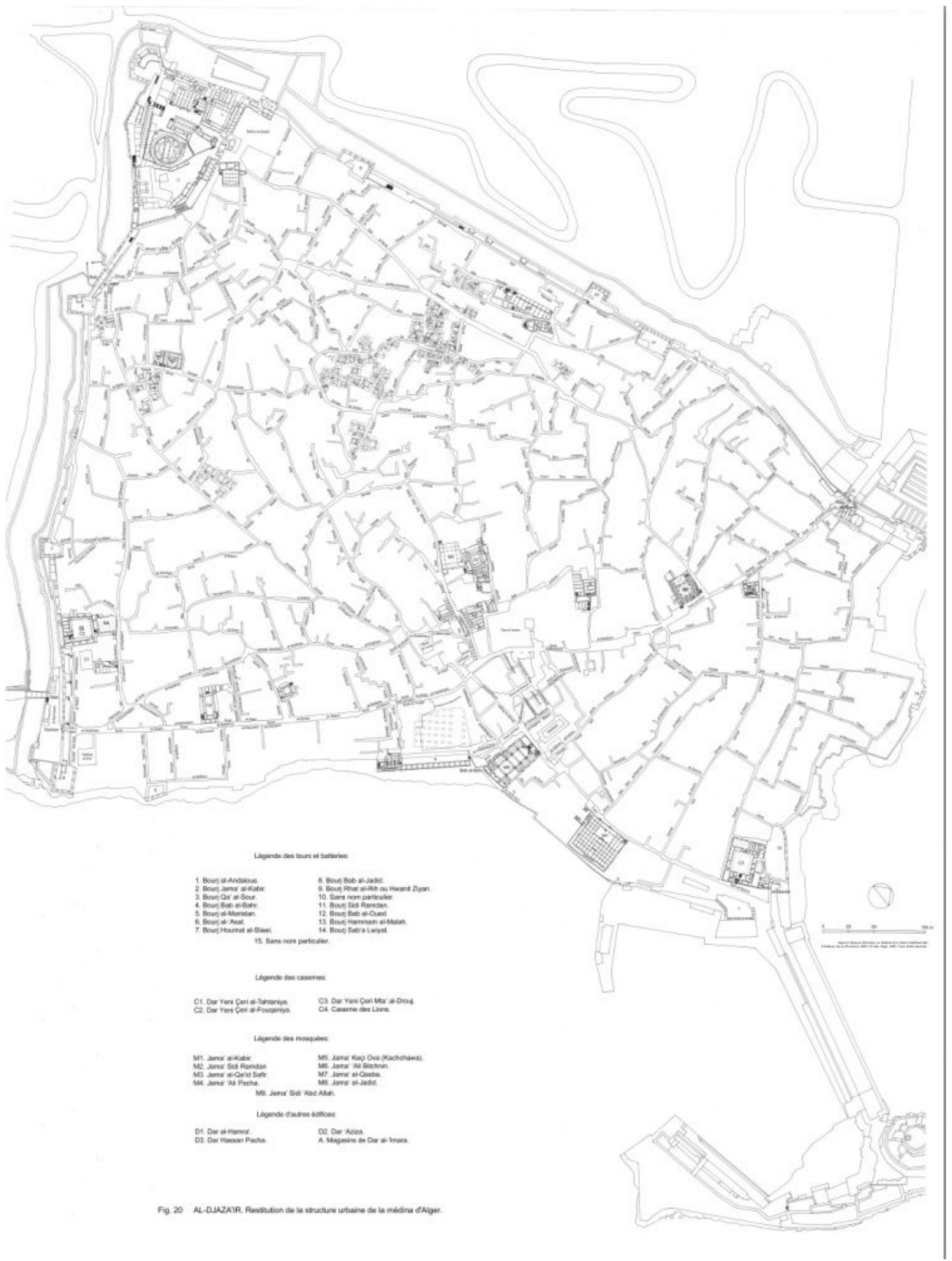

Fig. 9 - Sakina Missoum, "Al-Djaza'ir. Restitution of the urban structure of the Algiers medina," Alger à L'époque Ottomane: La Médina et La Maison Traditionnelle (Aix-en-Provence: Edisud, 2003). 


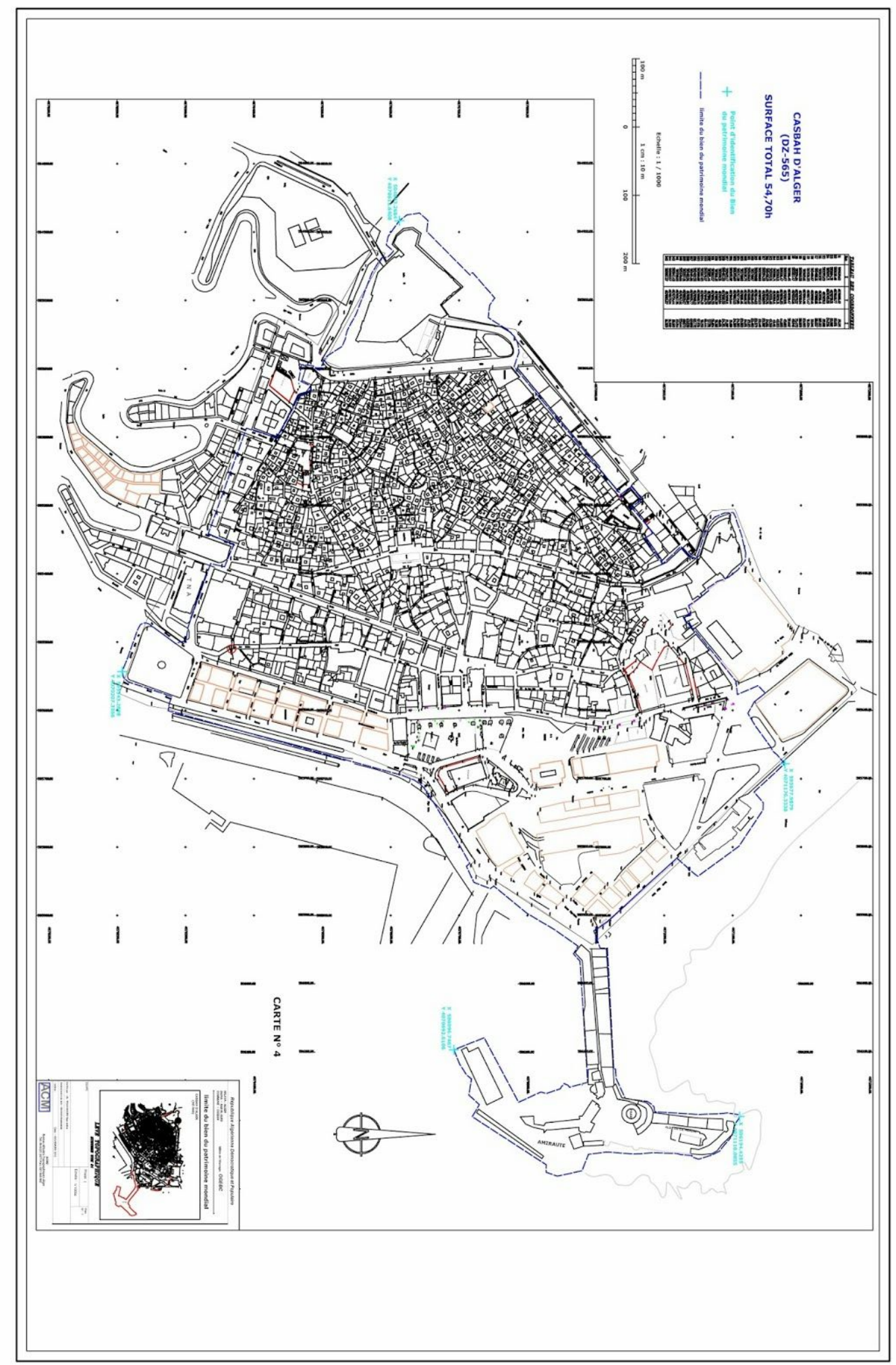

Fig. 10 - UNESCO, Kasbah of Algiers - Map of the inscribed property, 1992, http://whc.unesco.org/en/list/565/multiple=1\&unique number=667 


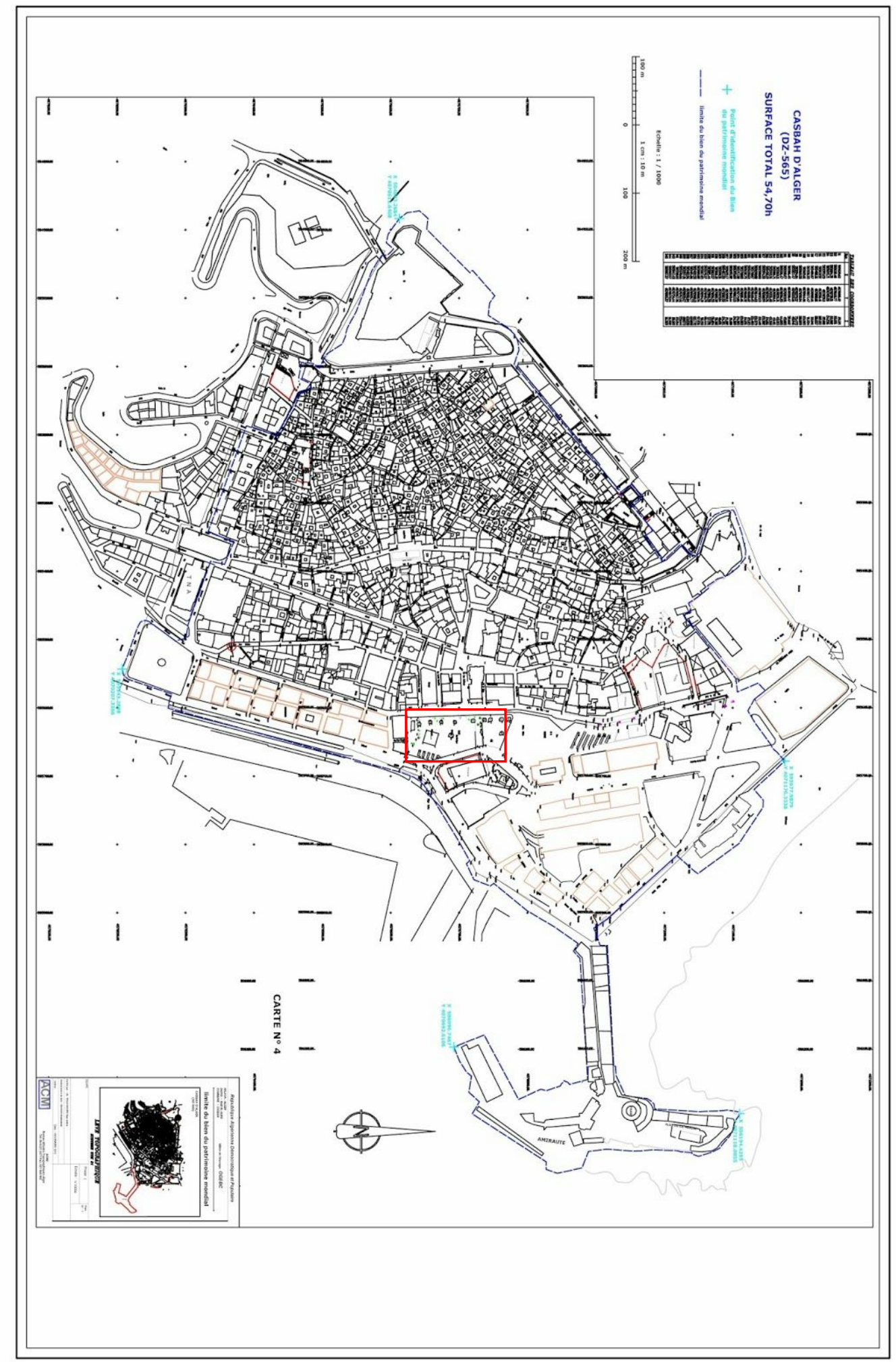

Fig. 11 - UNESCO, Kasbah of Algiers - Map of the inscribed property, 1992,

http://whc.unesco.org/en/list/565/multiple=1\&unique number=667, Place du Gouvernement (now Place des Martyrs) highlighted. 


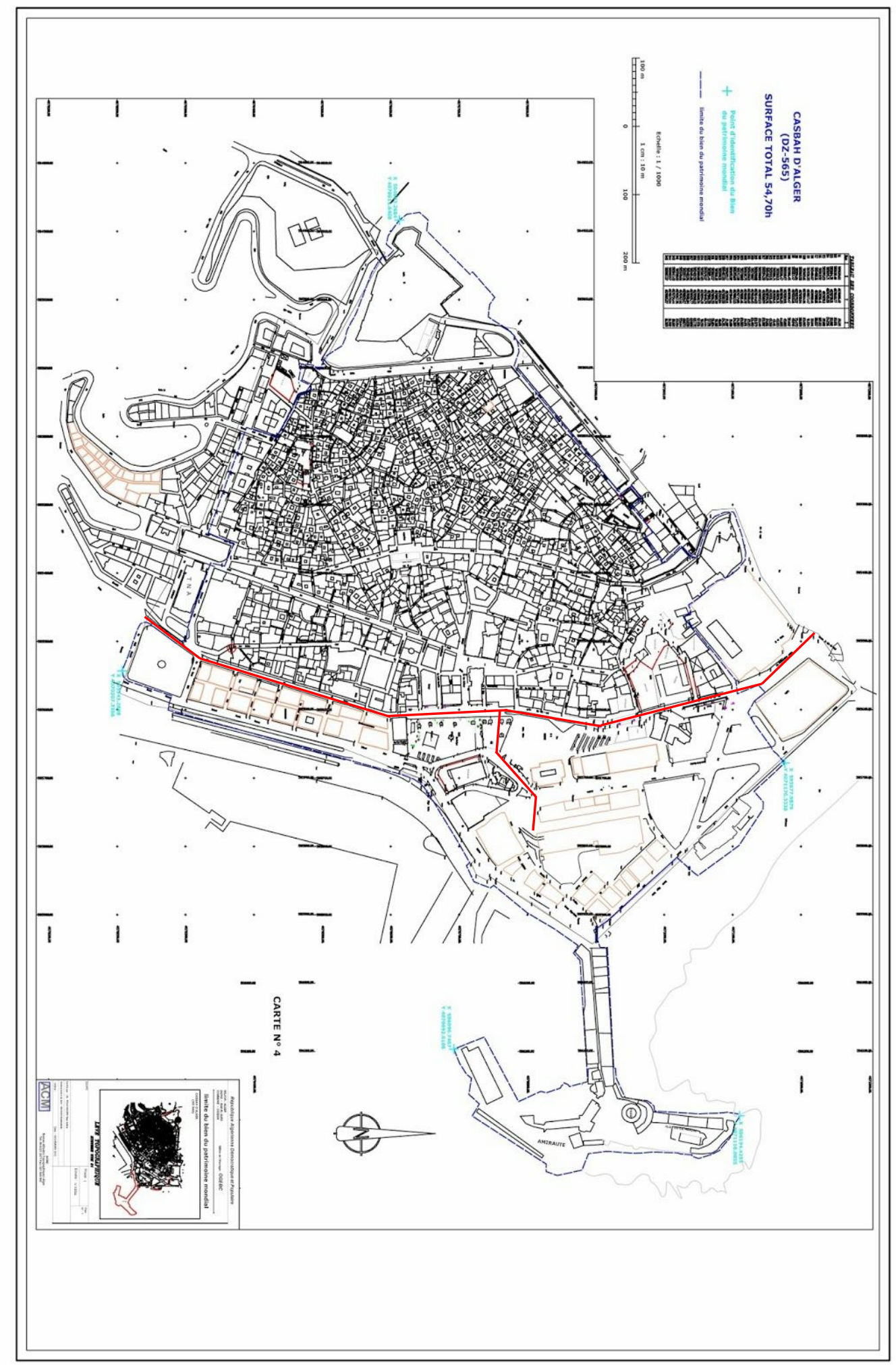

Fig. 12 - UNESCO, Kasbah of Algiers - Map of the inscribed property, 1992,

http://whc.unesco.org/en/list/565/multiple=1\&unique number=667, Bab Azzoun, Bab el-Oued, and Marine streets highlighted. 


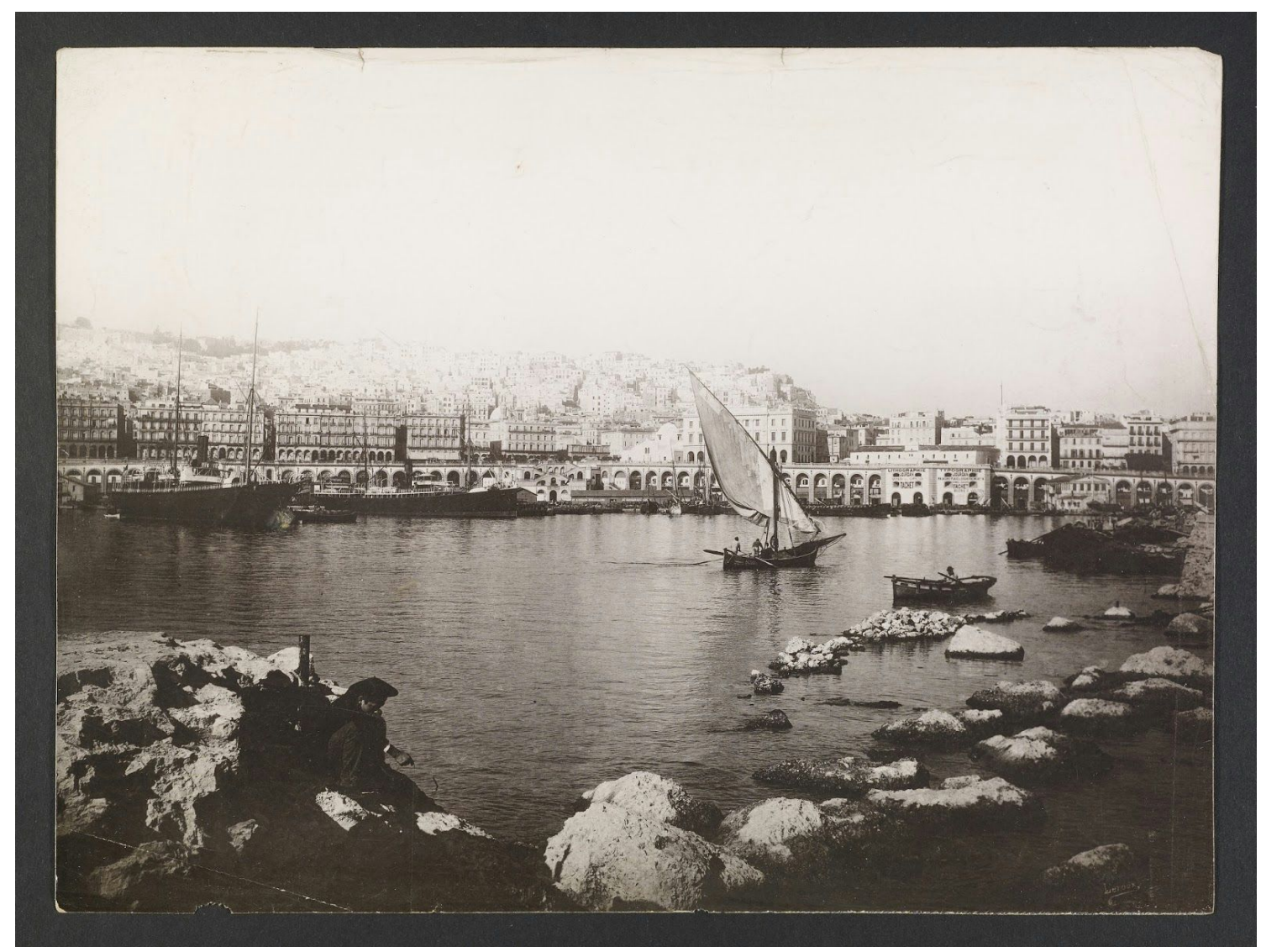

Fig. 13 - Alexandre Leroux, Algiers Harbour, 187-, Getty Research Institute, http://hdl.handle.net/10020/2008r3 4300.

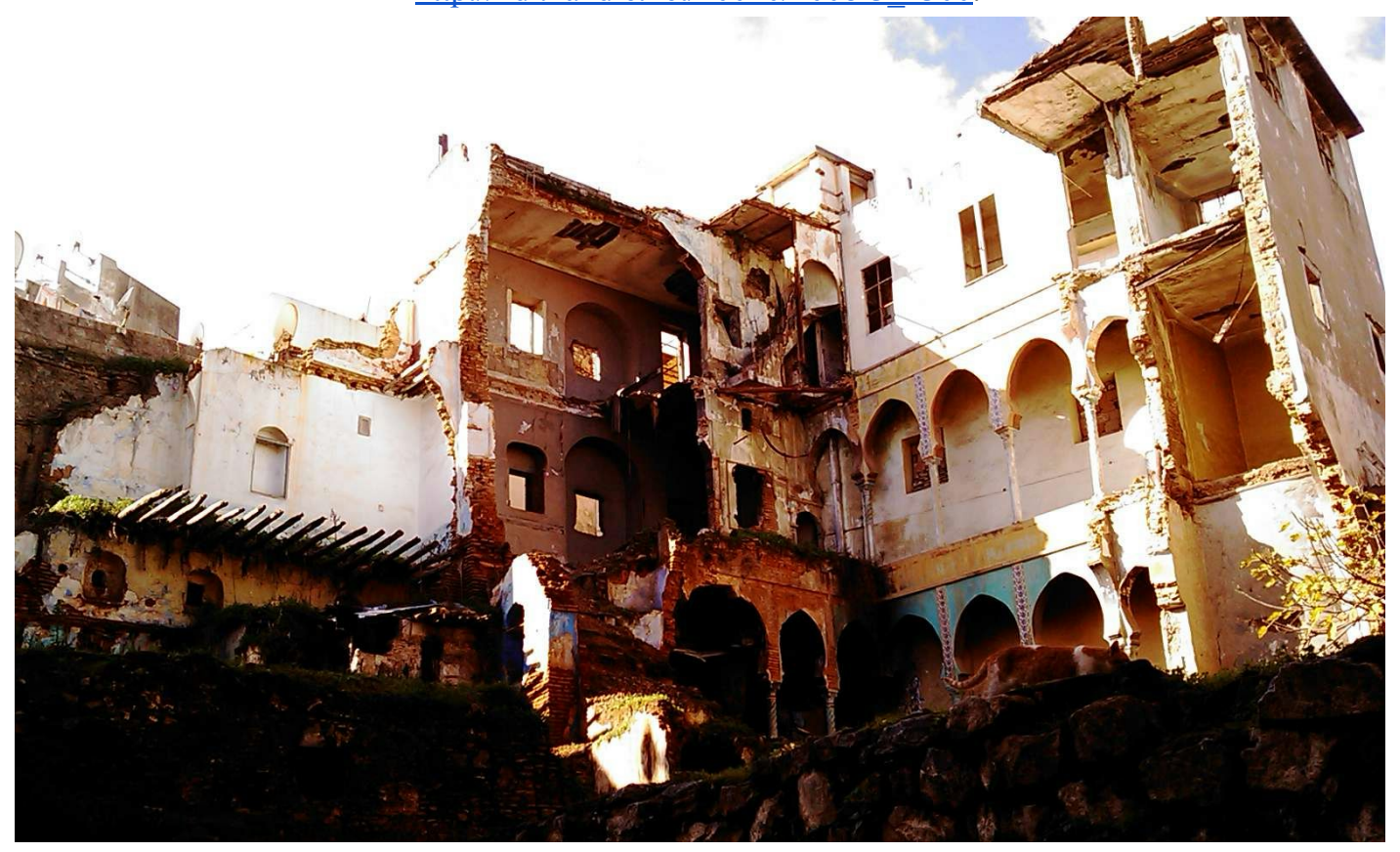

Fig. 14 - Ruins of Ali La Pointe house, September 30, 1957,

https://en.wikipedia.org/wiki/Battle of Algiers (1956\%E2\%80\%9357)\#/media/File:Casbah-cache-Ali-lapointe.jpg 


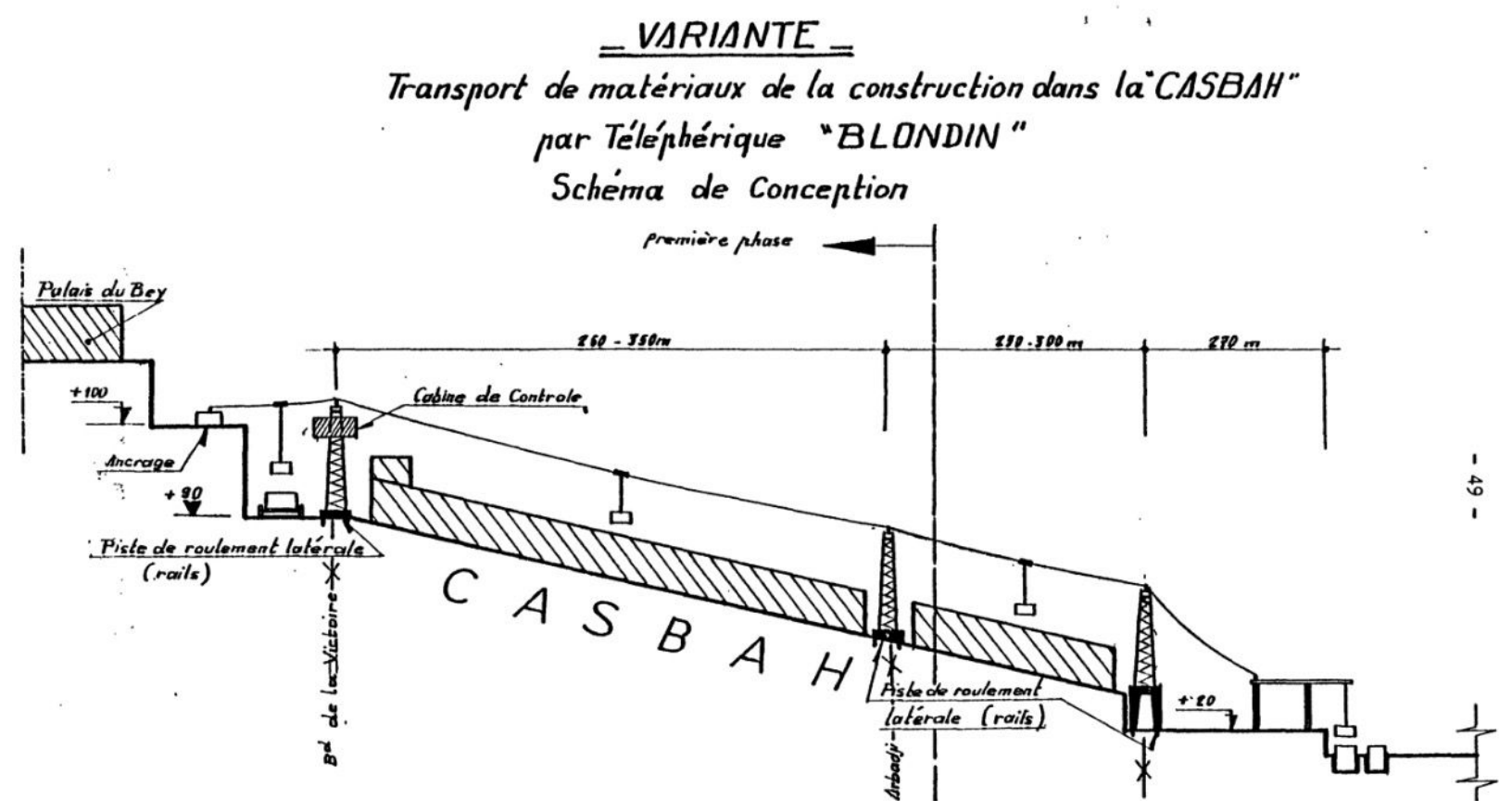

Fig. 15 - Dorothée Vauzelles Barbier et al., Schematic from "Mission d'Assistance préparatoire Revalorisation de la Casbah d'Alger" (Paris: UNESCO, 1978), http://unesdoc.unesco.org/images/0003/000321/032150fb.pdf, 49.
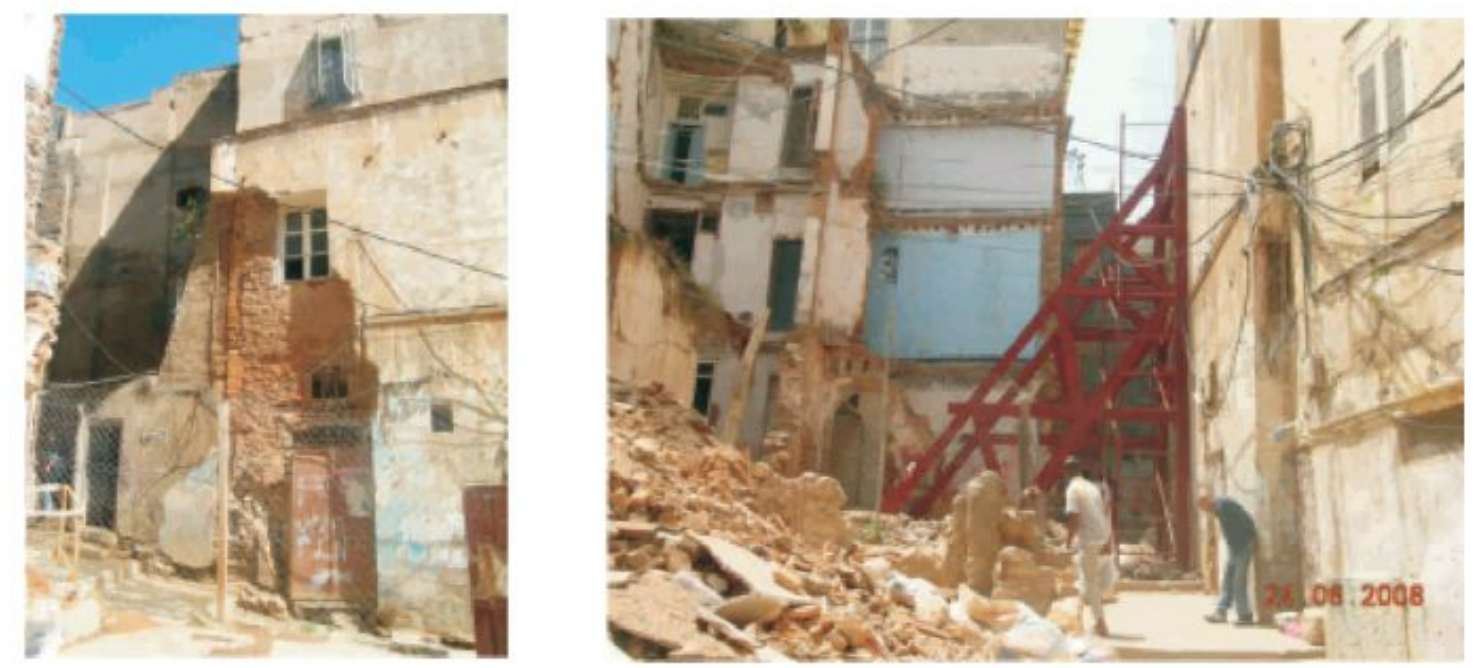

Fig. 16 -Plan Permenant de Sauvegarde et de Mise en Valeur le Secteur Sauvegardé de la Casbah d'Alger, Before work and after work, http://www.casbahdalger.dz/001.pdf. 